\title{
Sedimentology and palynology of the Lower Cretaceous succession of central Spitsbergen: integration of subsurface and outcrop data
}

\author{
Sten-Andreas Grundvåg' ${ }^{1}$ Mads Engholm Jelby², Kasia Kamila Śliwińska ${ }^{3}$, \\ Henrik Nøhr-Hansen ${ }^{3}$, Tore Aadland ${ }^{4}$, Sara Elvelund Sandvik ${ }^{5}$, Ingrid Tennvassås' \\ Thea Engen' \& Snorre Olaussen 6
}

\author{
${ }^{1}$ Department of Geosciences, UiT The Arctic University of Norway, P.O. Box 6050 Langnes, N-9037 Tromsø, Norway. \\ ${ }^{2}$ Natural History Museum of Denmark, University of Copenhagen, Øster Voldgade 5-7, DK-1350 Copenhagen K, Denmark. \\ ${ }^{3}$ Geological Survey of Denmark and Greenland (GEUS), Øster Voldgade 10, DK-1350 Copenhagen K, Denmark. \\ ${ }^{4}$ Department of Earth Science, University of Bergen, P.O. Box 7803, N-5020 Bergen, Norway. \\ ${ }^{5}$ Lundin Norway AS, P.O. Box 247, N-1326 Lysaker, Norway. \\ ${ }^{6}$ Department of Arctic Geology, The University Centre in Svalbard, P.O. Box 156, N-9171 Longyearbyen, Norway.
}

E-mail corresponding author (Sten-Andreas Grundvåg): Sten-Andreas.Grundvag@uit.no

\begin{abstract}
The Lower Cretaceous succession in Svalbard is commonly considered as an important analogue to age-equivalent strata on the Barents Shelf which are sporadically targeted by exploration wells. In this study, the stratigraphic and genetic relationship between the Rurikfjellet (open marine), Helvetiafjellet (paralic) and Carolinefjellet (open marine) formations of the Lower Cretaceous succession in Svalbard is evaluated by combining sedimentological outcrop studies with well log and core data across Nordenskiöld Land, central Spitsbergen. Sedimentological characteristics and stratigraphic units are mapped within a refined dinocyst biostratigraphic framework, enabling relatively well-constrained palaeogeographic reconstructions. The Valanginian-lowermost Barremian Rurikfjellet Formation consists of a lower shale-dominated unit of offshore origin which grades upwards into storm-reworked lower shoreface sandstones displaying hummocky cross-stratification. Local occurrences of prodeltaic successions and thick successions of gravity flow deposits containing coal-bearing slump blocks of delta plain origin in some wells, reveal a late Hauterivian progradational pulse which has previously not been recorded in Svalbard. The lower Barremianlower Aptian Helvetiafjellet Formation consists of fluvial braidplain and paralic deposits which rest unconformably on the Rurikfjellet Formation across the entire study area, reflecting regional uplift and widespread subaerial exposure prior to the onset of paralic deposition. The Helvetiafjellet Formation exhibits increased marine influence upwards, and in the investigated cores the uppermost part of the unit consists of wave-reworked mouth-bar deposits which are truncated by a transgressive conglomerate lag dominated by extrabasinal lithic clasts and intraformational siderite clasts. An up to $10 \mathrm{~m}$-thick, regionally extensive, organic-rich (TOC up to 2.1 wt.\%) shale unit of early Aptian age marks the base of the overlying Carolinefjellet Formation. The shale accumulated during a regional flooding event which drowned and eventually transformed the Helvetiafjellet Formation coastal plain into a shallow shelf. The organic facies of the shale unit (Type II-III kerogen) and a high $\mathrm{Pr} / \mathrm{Ph}$ ratio (>2), in combination with abundant long-chained n-alkanes, suggest that the unit was deposited in a suboxic paralic marine environment strongly influenced by input of terrestrial organic matter. The investigated succession exhibits stratigraphic and petrographic resemblance to age-equivalent strata in NE Greenland, suggesting that these successions may have formed part of the same drainage system located on the northwestern margin of the Barents Shelf. Thus, by highlighting the Early Cretaceous palaeogeographic evolution in Svalbard, this study contributes to the regional stratigraphic understanding of the Lower Cretaceous succession on the wider northern Barents Shelf.
\end{abstract}

Keywords: Svalbard, northern Barents Shelf, Mesozoic, Early Cretaceous palaeogeography, facies analysis, sequence stratigraphy

Received 9. November 2018 / Accepted 28. March 2019 / Published online 26. June 2019

Grundvåg, S.A., Jelby, M.E., Śliwińska, K.K., Nøhr-Hansen, H., Aadland, T., Sandvik, S.E., Tennvassås, I., Engen, T. \& Olaussen, S. 2019 : Sedimentology and palynology of the Lower Cretaceous succession of central Spitsbergen: integration of subsurface and outcrop data. Norwegian Journal of Geology 99, 247-278. https://dx.doi.org/10.17850/njg006. 


\section{Introduction}

The Lower Cretaceous succession in Svalbard (Fig. 1) consists of the Rurikfjellet (open marine), the Helvetiafjellet (paralic) and the Carolinefjellet (open marine) formations (e.g., Dypvik et al., 1991a; Gjelberg \& Steel, 1995; Fig. 2). Early work on the succession mostly focused on lithostratigraphic aspects (Parker, 1967; Nagy, 1970), and particularly the Barremian Helvetiafjellet Formation (Fig. 2) received considerable attention due to its coal content, possible local reservoir potential, and for representing a possible analogue to time-equivalent reservoir units for oil and gas in the Barents Sea (Edwards, 1976, 1979; Smith \& Pickton, 1976; Steel, 1977; Nemec et al., 1988; Nemec, 1992; Gjelberg \& Steel, 1995). Coal seams in the Helvetiafjellet Formation were briefly mined at Advent City and Hiorthamn in Adventfjorden and at Bohemanneset at the northern shore of Isfjorden (Fig. 1) during the early 1900s. Despite these early efforts, only limited volumes of coal have been extracted from the unit, and there is presently no commercial interest for the unit in regard to coal exploration. The Lower Cretaceous succession was further subject to intense mapping during the onshore oil and gas exploration campaigns in central Spitsbergen between 1963 and 1994. Following these campaigns, some hydrocarbon shows and technical gas discoveries were reported in some drilled wells (e.g., the 7714/3-1 Ishøgda I, 7815/10-1 Colesbukta and 7816/12-1 Reindalspasset I wells; Nøttvedt et al., 1993). In addition, a coal exploration well drilled in the inner part of Adventdalen in the early 1980s incidentally struck dry gas in Lower Cretaceous strata. However, the gas was of unknown origin and in non-commercial volumes (Mackenzie et al., 1983). Exploration for moveable hydrocarbons onshore Svalbard was eventually abandoned in the early 1990s following the overall

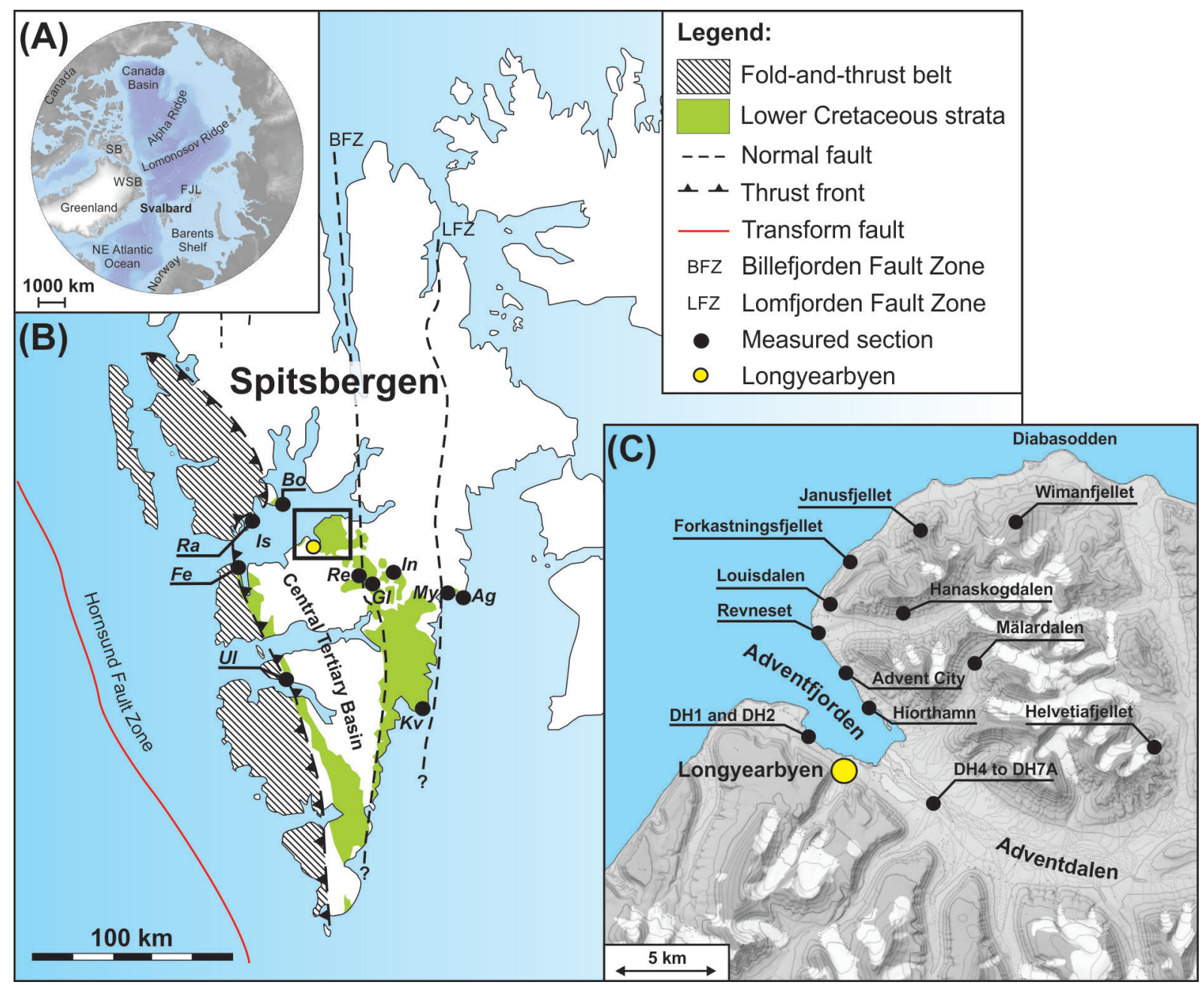

Figure 1. (A) Map showing the location of Svalbard on the northwestern corner of the Barents Shelf. FJL - Franz Josef Land, SB - Sverdrup Basin, WSB - Wandel Sea Basin. (B) Map of Spitsbergen showing the position of the West Spitsbergen fold-and-thrust belt, the Central Tertiary Basin, and the distribution of Lower Cretaceous strata. The black square denotes the location of the main study area in central Spitsbergen. The yellow dot indicates the location of Longyearbyen. The black dots indicate the locations of investigated sections. Ag - Agardhfjellet, Bo Bohemanflya, Fe - Festningen, Gl - Glitrefjellet, In - Innerknausen, Is - Isfjorden, Kv - Kvalvågen, My - Myklegardfjellet, Ra - Ramfjellet, Re - Reindalspasset (well 7816/12-1), Ul - Ullaberget. (C) Map of the study area showing the location of the $\mathrm{CO}_{2}$ well sites and nearby outcrop sections. The map is modified from the Norwegian Polar Institute (http://toposvalbard.npolar.no). 


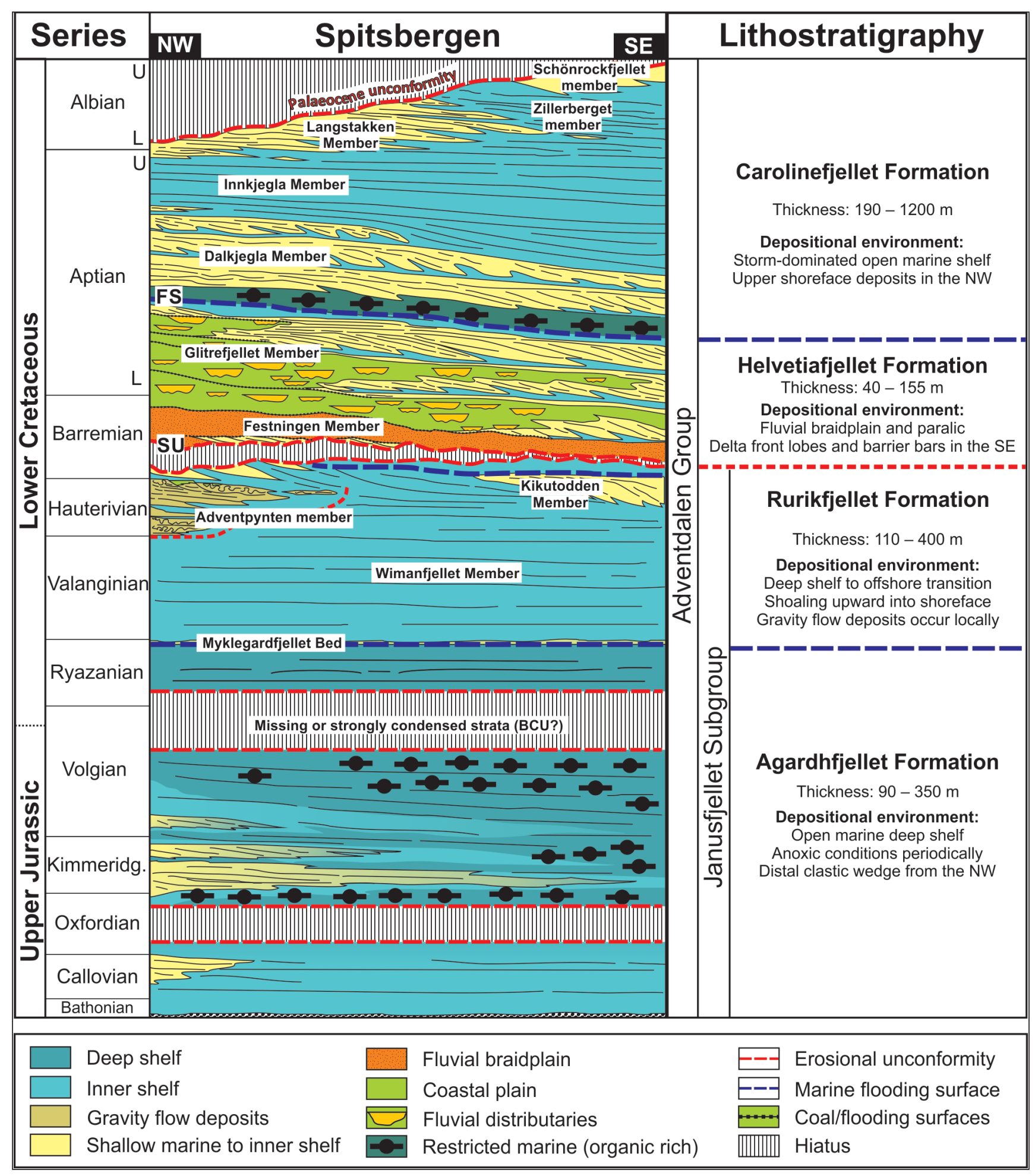

Figure 2. Stratigraphic cross-section from the northwest to southeast of Spitsbergen showing the regional development of the Upper Jurassic to Lower Cretaceous Adventdalen Group. The Myklegardfjellet Bed represents the base of the Lower Cretaceous succession although Ryazanian strata occur in the uppermost part of the Agardhfjellet Formation. The underlying hiatus probably corresponds to the Base Cretaceous Unconformity (BCU) in the offshore basins. The cross-section integrates data compiled from Parker (1967), Nagy (1970), Steel \& Worsley (1984), Dypvik et al. (1991a), Gjelberg \& Steel (1995), Midtkandal et al. (2007, 2008), Hurum et al. (2016b), Koevoets et al. (2016; 2018), Grundvåg et al. (2017), and this study. FS - lower Aptian flooding surface; SU - lower Barremian subaerial unconformity.

disappointing results. Most of the subsurface data generated during the exploration campaigns are largely unavailable for the public and still remain unpublished, only being sporadically mentioned in previous literature (e.g., Nøttvedt et al., 1993). More recently, parts of the Lower Cretaceous succession in the subsurface of central Spitsbergen have been penetrated by seven fully cored wells drilled in relation to a $\mathrm{CO}_{2}$ sequestration project 
in the vicinity of Longyearbyen (Fig. 1; Braathen et al., 2012). Although the Lower Cretaceous succession was initially regarded as overburden to the targeted Triassic to Middle Jurassic $\mathrm{CO}_{2}$ reservoir sandstones, aquifer potential (largely due to fractures) was proven in the Festningen Member of the Helvetiafjellet Formation (e.g., Braathen et al., 2012; Magnabosco et al., 2014). However, the unit was disregarded as a possible $\mathrm{CO}_{2}$ reservoir due to its direct connection to the land surface along many valley and fjord sides. The investigations also demonstrated that the shale-dominated Rurikfjellet Formation forms part of a viable top seal unit (Braathen et al., 2012; Bohloli et al., 2014). To date, there have been few attempts to link outcrop and subsurface observations of the Lower Cretaceous succession in Svalbard (e.g., Grundvåg et al., 2017), despite its relevance for understanding Lower Cretaceous play models and related petroleum system elements on the northern Barents Shelf (e.g., the presence of inferred sandstone-dominated Barremian to Aptian delta-scale clinoforms and the distribution of oil-prone source rocks demonstrated in the Fingerdjupet Subbasin by well 7321/9-1S).

This contribution reports on the sedimentology and biostratigraphy of the Lower Cretaceous succession in Nordenskiöld Land, central Spitsbergen, by combining well and outcrop data. The genetic relationship between the Rurikfjellet, Helvetiafjellet and Carolinefjellet formations is thoroughly documented, with special attention given to new subsurface observations. In addition, a refined biostratigraphic age model based on dinoflagellates (dinocysts) is presented. The age data aid correlation of wells and selected outcrop sections across the study area, including the nearly continuous outcrop section at Festningen in the westernmost part of Isfjorden (Fig. 1). Thus, the findings of the present study contribute to the regional stratigraphic and palaeogeographic understanding of the Lower Cretaceous succession on the northern Barents Shelf.

\section{Geological framework}

\section{Tectonic setting}

The study area is confined to Nordenskiöld Land on Spitsbergen, the largest island of the Svalbard archipelago, Norway (Fig. 1). The archipelago represents the uplifted and exposed northwestern corner of the Barents Shelf. The bulk of the Mesozoic strata on Spitsbergen crop out along the margins of the NNW-SSE-trending Central Tertiary Basin (Fig. 1B). Due to Paleogene transpressional tectonics (Steel et al., 1985), the Mesozoic strata are steeply dipping or vertically tilted in western Spitsbergen, and dip towards the southwest at a low angle $\left(<3^{\circ}\right)$ in central and eastern Spitsbergen.
During the Early Cretaceous, Svalbard was situated at $63-66^{\circ} \mathrm{N}$, as part of a large circum-Arctic platform located in the northwestern corner of the Eurasian continental plate (Fig. 3; Steel \& Worsley, 1984; Torsvik et al., 2002). Svalbard was partly covered by a shallow epicontinental sea with shorelines facing a gently southward-sloping ramp-type shelf (Fig. 3; Midtkandal \& Nystuen, 2009). The Svalbard platform was mostly dominated by post-rift subsidence, but syn-sedimentary collapse features in proximity to regional lineaments in eastern Spitsbergen indicate some fault activity (Nemec et al., 1988; Onderdonk \& Midtkandal, 2010). Increased tectonic activity including enhanced differential uplift of the Svalbard platform in the Barremian promoted the formation of a regionally extensive subaerial unconformity across Svalbard (Steel \& Worsley, 1984; Gjelberg \& Steel, 1995; Maher, 2001; Midtkandal et al., 2008). The differential uplift was accompanied by widespread igneous activity attributed to the formation of the High Arctic Large Igneous Province (HALIP) (Maher, 2001; Senger et al., 2014; Polteau et al., 2016). Zircon datings indicate that the magmatism was episodic and short-lived with peak activity in the late Barremianearly Aptian (Corfu et al., 2013). The Early Cretaceous climate of Svalbard is debated (Pickton, 1981; Århus, 1991; Maher et al., 2004; Mutrux et al., 2008; Price \& Nunn, 2010; Price \& Passey, 2013; Vickers et al., 2016, 2018). However, the presence of ornithopod dinosaur tracks, fossilised deciduous conifers and ginkgo trees, and bituminous coal seams in the Helvetiafjellet Formation point to a warm temperate (mean annual temperatures of $7-10^{\circ} \mathrm{C}$ ) and humid climate in the Barremian to early Aptian (Nemec, 1992; Hurum et al., 2016a).

Svalbard has been subjected to recurring uplift since the Late Cretaceous through Cenozoic, as well as glaciations from the Pliocene and onwards. As a result, Upper Cretaceous strata are not present in Svalbard (Fig. 2). However, reworked Late Cretaceous terrestrial and marine microfloras reported in the Paleocene strata of southern Spitsbergen suggest that Upper Cretaceous strata may once have been present (Smelror \& Larssen, 2016).

\section{Lower Cretaceous lithostratigraphy}

The Lower Cretaceous succession of Svalbard belongs to the Adventdalen Group comprising the Upper Jurassic Agardhfjellet Formation (not considered here; see Koevoets et al., 2016; 2019), and the Rurikfjellet, Helvetiafjellet and Carolinefjellet formations (Parker, 1967; Nagy, 1970; Dypvik et al., 1991a; Fig. 2).

The Rurikfjellet Formation (Valanginian-lowermost Barremian; Dypvik et al., 1991a; This study) is generally around $200 \mathrm{~m}$ thick, and subdivided into the lower shale-dominated Wimanfjellet Member and the upper 


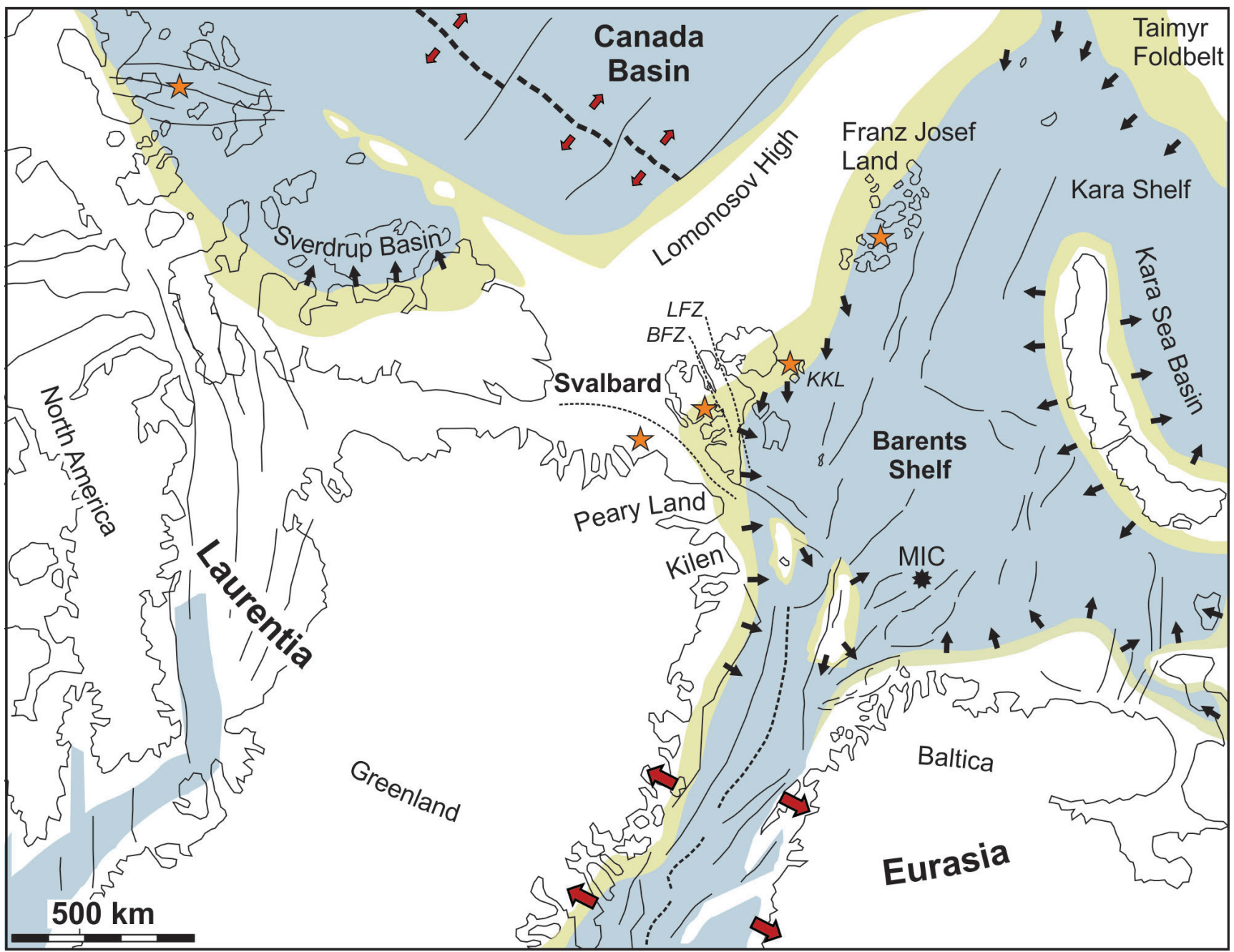

$\square$ Undifferentiated terrain $\square$ Shallow marine/paralic $\square$ Open marine shelf $\Rightarrow$ Migration direction $\Rightarrow$ Rifting/sea-floor spreading

Figure 3. Palaeogeographic reconstruction showing the location of Svalbard during the Early Cretaceous. Black arrows indicate shoreline migration directions. Red arrows indicate rifting, and orange stars indicate areas where former igneous activity has been recorded. The map is based on Steel \& Worsley (1984), Dypvik et al. (2002), Torsvik et al. (2002), Tullius et al. (2014), Marin et al. (2016) and Grundvåg \& Olaussen (2017). BFZ - Billefjorden Fault Zone; LFZ - Lomfjorden Fault Zone; KKL - Kong Karls Land; MIC - Mjølnir Impact Crater.

sandstone-rich Kikutodden Member (Fig. 2; Midtkandal et al., 2008). The base of the Wimanfjellet Member is defined by the Myklegardfjellet Bed; an up to $10 \mathrm{~m}$-thick glauconitic, plastic clay unit (Fig. 2). Locally, an up to 130 m-thick succession of mass-flow deposits occur in the lower part of the Rurikfjellet Formation (MorkJansson et al., 2010; Braathen et al., 2012). Henceforth, this unit is informally referred to as the Adventpynten member (Fig. 2).

The Helvetiafjellet Formation (Barremian-lower Aptian; Grøsfjeld, 1992; This study) is 40-155 $\mathrm{m}$ thick and consists of the lower sandstone-dominated Festningen Member and the upper heterolithic and coal-bearing Glitrefjellet Member (Parker, 1967; Midtkandal et al., 2008). The formation represents deposition in a fluvial to paralic setting (Steel, 1977; Steel et al., 1978; Nemec et al., 1988; Nemec, 1992; Gjelberg \& Steel, 1995; Midtkandal et al., 2007). The Barremian subaerial unconformity defines the base of the formation across most of Svalbard (Fig. 2; Steel \& Worsley, 1984; Gjelberg \& Steel, 1995; Maher, 2001).

The Carolinefjellet Formation (lower Aptian-middle Albian; Nagy, 1970; Århus, 1991; Hurum et al., 2016b; This study) is up to $1200 \mathrm{~m}$ thick, and consists of five alternatingly sandstone-rich and shale-dominated units; the Dalkjegla, Innkjegla, Langstakken, Zillerberget and Schönrockfjellet members (Parker, 1967; Nagy, 1970; Fig. 2). The formation represents deposition in open marine shelf environments (Nagy, 1970; Maher et al., 2004; Mutrux et al., 2008), and is truncated by the Paleocene (Danian) unconformity (Fig. 2; Nagy, 1970). 
Table 1. Summary of facies associations.

\begin{tabular}{|c|c|c|c|c|c|}
\hline FA & $\begin{array}{c}\text { Depositional } \\
\text { environments }\end{array}$ & Lithology & Geometry and sedimentary structures & Trace fossils & BI \\
\hline \multicolumn{6}{|c|}{ Rurikfjellet Formation } \\
\hline 1 & Offshore shelf & $\begin{array}{l}\text { Claystone to sandy siltstone. } \\
\text { Siderite beds and concretions } \\
\text { in places. }\end{array}$ & $\begin{array}{l}\text { Up to } 200 \mathrm{~m} \text { thick unit, tabular at the scale } \\
\text { of outcrop. Fine lamination dominates, } \\
\text { normally graded and massive beds occur. }\end{array}$ & $\begin{array}{l}\text { Phycosiphon incertum, } \\
\text { Chondrites, Planolites, and } \\
\text { Nereites missouriensis. }\end{array}$ & $0-3$ \\
\hline 2 & $\begin{array}{l}\text { Offshore transition } \\
\text { to lower shoreface }\end{array}$ & $\begin{array}{l}\text { Siltstones to fine-grained } \\
\text { sandstones. Siderite concretions } \\
\text { and glendonites occur in places. }\end{array}$ & $\begin{array}{l}\text { Vertically stacked, coarsening and } \\
\text { thickening-upwards units, } 2-10 \mathrm{~m} \text { thick, } \\
\text { with tabular geometries. Abundant wave } \\
\text { ripple cross-lamination and hummocky } \\
\text { cross-stratification. Heterolithic and thin- } \\
\text { bedded lower parts, amalgamated and } \\
\text { thick-bedded upper parts. }\end{array}$ & $\begin{array}{l}\text { Planolites, } \\
\text { Schaubcylindrichnus freyi, } \\
\text { Palaeophycus, Nereites mis- } \\
\text { souriensis, Thalassinoides, } \\
\text { Spongeliomorpha, Chondrites } \\
\text { and Phycosiphon incer- } \\
\text { tum. Skolithos, Rosselia, } \\
\text { Teichichnus, Diplocraterion } \\
\text { habichi and Ophiomorpha } \\
\text { occur in the thicker sand- } \\
\text { stone beds. }\end{array}$ & $3-5$ \\
\hline 3 & $\begin{array}{l}\text { Prodelta slope to } \\
\text { delta front }\end{array}$ & $\begin{array}{l}\text { Mudstones and siltstones with } \\
\text { interbedded coarse-grained } \\
\text { muddy sandstones. }\end{array}$ & $\begin{array}{l}\text { Forms a } 30-40 \mathrm{~m} \text { thick mudstone-domi- } \\
\text { nated, sandstone-rich, coarsening-upward } \\
\text { unit in Wells DH1 and DH2. Erosively } \\
\text { based, normally graded beds with abundant } \\
\text { soft-sediment deformation. Current ripples } \\
\text { cross-lamination occur in the sandstones. }\end{array}$ & $\begin{array}{l}\text { Phycosiphon incertum, } \\
\text { Planolites, Palaeophycus and } \\
\text { Thalassinodes. }\end{array}$ & $1-2$ \\
\hline 4 & $\begin{array}{l}\text { Base-of-slope mass } \\
\text { transport complex }\end{array}$ & $\begin{array}{l}\text { Poorly sorted diamicts } \\
\text { composed of matrix- } \\
\text { supported sandy mudstone } \\
\text { with subrounded intraclasts } \\
\text { consisting of sandy granules and } \\
\text { claystone. Cleaner fine-grained } \\
\text { sandstones, and mudstones and } \\
\text { siltstone interbeds are present. }\end{array}$ & $\begin{array}{l}\text { Up to } 130 \mathrm{~m} \text { thick sandstone-dominated } \\
\text { succession in wells DH1 and DH2. } \\
\text { The diamicts have a chaotic fabric, but } \\
\text { commonly show inverse to normal grading } \\
\text { and soft-sediment deformation structures. } \\
\text { Micro-faults (few cm offset), distorted } \\
\text { bedding and folded heterolithic units occur } \\
\text { frequently. Plane-parallel lamination and } \\
\text { current ripple cross-lamination occur in } \\
\text { the sandstone divisions. An allochthonous } \\
\text { block of coastal plain deposits occur in } \\
\text { DH2. }\end{array}$ & $\begin{array}{l}\text { Trace fosssils only occur in } \\
\text { the interbedded mudstones } \\
\text { and siltstones and include } \\
\text { Planolites, Phycosiphon } \\
\text { incertum, Chondrites, } \\
\text { rare Palaeophycus and } \\
\text { Schaubcylindrichnus freyi. }\end{array}$ & $3-4$ \\
\hline
\end{tabular}

\section{Helvetiafjellet Formation}

$5 \quad$ Fluvial braidplain

Fine- to coarse-grained sandstones and pebble conglomerates.

6 Floodplain to interdistributary bay Crevasse splay Delta front Fluvial distributary channel
Mudstones and siltstones with subordinate thin coals and coaly shale.

Very fine- to medium-grained sandstones with thin siltstone interbeds. Lithic conglomerate lags occur at the base of thicker beds.

Fine- to coarse-grained sandstones and conglomerates with thin interbeds of siltstone. Concretions and layers of siderite occur.

Fine- to very coarse-grained sandstones and lithic conglomerates.
Erosionally-based, cross-stratified, sheetlike sandstone. Internal scours and multilateral stacking of units are commonly observed. Lateral thickness variations in the range of 2-8 m occur over short distances (few tens of metres).

$\mathrm{Up}$ to $5 \mathrm{~m}$ thick tabular units. Fine lamination dominates. Leaves, plant fragments, rootlets, and thin coals with associated seat earths are common. Bivalves occur in places.

Upwards coarsening and thickening units with tabular geometries, generally $<2$ m thick. Beds display plane-parallel lamination, current ripple cross-lamination, trough cross-stratification, or have a massive appearance. Erosional truncations occur.

Upwards coarsening and thickening units up to $10 \mathrm{~m}$ thick with tabular geometries and locally displaying large foresets. Amalgamation increase upward. Current ripple cross-lamination, wave-ripple crosslamination, plane-parallel stratification, and tabular cross-stratification occur.

Up to $5 \mathrm{~m}$ thick, trough and tabular cross-stratified sandstone bodies with erosive, concave-up bases and vague fining-up grain-size trends. Planeparallel stratification, current ripple cross-lamination, and lateral accretion surfaces are common. Double mud drapes, flaser bedding, and bi-directional crossstratification are present in places.
Rootlets commonly occur in $\quad 0-2$ the upper part of the sandstone bodies.

Rootlets and simple sand-

filled traces occur.

Rootlets and Skolithos occur in top of some sandstone bodies.

Skolithos, Arenicolites, Planolites and Palaeophycus.

Rootlets commonly penetrate the upper part of the sandstone bodies. 


\begin{tabular}{|c|c|c|c|c|c|}
\hline FA & $\begin{array}{c}\text { Depositional } \\
\text { environments }\end{array}$ & Lithology & Geometry and sedimentary structures & Trace fossils & BI \\
\hline \multicolumn{6}{|c|}{ Carolinefjellet Formation } \\
\hline 10 & $\begin{array}{l}\text { Restricted marine } \\
\text { shelf }\end{array}$ & $\begin{array}{l}\text { Organic-rich claystone to } \\
\text { siltstone with interbedded very } \\
\text { fine- to fine-grained sandstones. } \\
\text { Pyrite and siderite nodules are } \\
\text { present. }\end{array}$ & $\begin{array}{l}\text { Up to } 10 \mathrm{~m} \text { thick, regionally extensive } \\
\text { dark grey to black, finely laminated shale } \\
\text { unit with total organic carbon contents } \\
\text { of wt. } 2 \% \text {. The unit shows an upward } \\
\text { increase in the abundance of lenticular- } \\
\text { bedded sandstones with wave ripple } \\
\text { cross-lamination. }\end{array}$ & $\begin{array}{l}\text { The ichnodiversity and } \\
\text { degree of bioturbation are } \\
\text { low, but tend to increase } \\
\text { upward. Arenicolites, } \\
\text { Palaeophycus, Gyrophyllites } \\
\text { and Schaubcylindrichnus } \\
\text { freyi occur in the interbed- } \\
\text { ded sandstones. }\end{array}$ & $0-3$ \\
\hline 11 & $\begin{array}{l}\text { Offshore transition } \\
\text { to lower shoreface }\end{array}$ & $\begin{array}{l}\text { Very fine- to fine-grained } \\
\text { sandstones with mudstone to } \\
\text { siltstone interbeds and rare } \\
\text { lithic conglomerate lags. Siderite } \\
\text { concretions and horizons are } \\
\text { common. }\end{array}$ & $\begin{array}{l}\text { Up to } 15 \mathrm{~m} \text { thick, tabular units with } \\
\text { heterolithic, thin-bedded lower parts and } \\
\text { thick-bedded, amalgamated, sandstone- } \\
\text { dominated upper parts. Hummocky cross- } \\
\text { stratification, wave-ripple cross-lamination } \\
\text { and various-sized scours are common. Shell } \\
\text { fragments, echinoderms, belemnites and } \\
\text { ammonites occur. }\end{array}$ & $\begin{array}{l}\text { Diplocraterion parallelum, } \\
\text { Rhizocorallium, Skolithos, } \\
\text { Arenicolites, Asterosoma, } \\
\text { Aulichnites, Palaeophycus, } \\
\text { Schaubcylindrichnus freyi } \\
\text { and Gyrophyllites occur } \\
\text { in the sandstones, and } \\
\text { Planolites and Thalassinoides } \\
\text { in the mudstones. }\end{array}$ & $\begin{array}{l}1-3 \\
(5-6 \text { in } \\
\text { places })\end{array}$ \\
\hline 12 & Open marine shelf & $\begin{array}{l}\text { Mudstones and siltstone with } \\
\text { thin interbeds of very fine- to } \\
\text { fine-grained sandstones. }\end{array}$ & $\begin{array}{l}\text { Up to } 10 \mathrm{~m} \text { thick, tabular-shaped units } \\
\text { alternating with FA } 11 \text {. Also forms an } \\
\text { up to } 150 \mathrm{~m} \text { thick mudstone-dominated } \\
\text { unit in the uppermost part of the studied } \\
\text { succession. The mudstones are laminated, } \\
\text { and the sandstones are thin-bedded } \\
\text { and lenticular, typically displaying wave } \\
\text { ripple cross-lamination and hummocky } \\
\text { cross-stratification. }\end{array}$ & $\begin{array}{l}\text { Phycosiphon, Planolites, } \\
\text { Thalassinoides, Palaeophycus, } \\
\text { Schaubcylindrichnus freyi } \\
\text { and Chondrites are com- } \\
\text { mon, and Arenicolites, } \\
\text { Zoophycos, Rosselia, } \\
\text { Asterosoma, Helminthopsis } \\
\text { and Cylindrichnus occur in } \\
\text { the sandstones. }\end{array}$ & $\begin{array}{l}2-4 \\
(5-6 \text { in } \\
\text { places })\end{array}$ \\
\hline
\end{tabular}

\section{Dataset and methods}

The dataset used in this study includes seven onshore sediment cores with a cumulative thickness of c. 1800 $\mathrm{m}$, as well as wireline gamma-ray logs from four of the wells (Fig. 4). Wells DH1 and DH2 are located $3 \mathrm{~km}$ to the northwest of Longyearbyen, and were drilled with c. $20 \mathrm{~m}$ of spacing (Fig. 1). Wells DH3 to DH7A are located in Adventdalen (Fig. 1), approximately $7 \mathrm{~km}$ to the southeast of the wells DH1 and DH2, and are referred to as the UNIS $\mathrm{CO}_{2}$ LAB well park, Longyearbyen (Braathen et al., 2012). Wells in this area are clustered together within a radius of c. $80 \mathrm{~m}$. Well DH5R is also included in two regional correlation panels (Figs. $5 \& 6$ ). The cores were measured bed-by-bed, and include descriptions of rock type, grain size, sorting, sedimentary structures, body and trace fossils, and degree of bioturbation (expressed following the bioturbation index (BI) of Taylor \& Goldring (1993). Data collected from nearby outcrops aided in the interpretation of facies and facies associations (Table 1) recorded in the cores and provided palaeocurrent flow directions.

A total of 38 dinoflagellate cyst (dinocyst) biostratigraphic samples have been collected and analysed. Biostratigraphic microscope slides were prepared at the Geological Survey of Denmark and Greenland (GEUS) by conventional techniques as described by Nøhr-Hansen (2012), and subsequently scanned for key species of the Lower Cretaceous. When possible, the assemblage is referred to the dinocyst zonation of Nøhr-Hansen (1993). Out of the 38 samples, the age of the Rurikfjellet
Formation is based on 33 samples collected from wells DH1 (eight samples), DH2 (nine samples) and DH5R (11 samples), as well as the Bohemanflya outcrop section (five samples). The age of the Helvetiafjellet Formation and the base of the Carolinefjellet Formation is based on five of the samples all collected from the DH2 well. The stratigraphic position of the samples is shown in Figs. 4 $\& 6$.

The non-weathered nature of the cores makes them ideal for geochemical studies and screening of potential source rocks. A total of five source-rock geochemical samples were collected in the basal shale unit of the Carolinefjellet Formation in well DH5R (Table 2). In addition, the dataset includes nine samples from the same stratigraphic unit in DH1 previously collected and analysed by Midtkandal et al. (2016) (Table 2). The TOC and Rock-Eval analyses of the DH5R samples were conducted by ENI, Norway, and samples from DH1 were analysed at the Institute for Energy Technology (IFE), Norway. The TOC content was determined by hightemperature combustion in a Leco SC-632 instrument. Prior to combustion, the rock samples were crushed and treated with diluted $\mathrm{HCl}$ to remove carbonate minerals. A Rock-Eval 6 instrument was used for Rock-Eval pyrolysis, and the Jet-Rock 1 standard was run and checked against the acceptable range given in NIGOGA ( $4^{\text {th }}$ edition) for every tenth sample. The temperature program was $300^{\circ} \mathrm{C}$ for 3 minutes with the temperature subsequently increased at a gradient of $25^{\circ} \mathrm{C} / \mathrm{min}$ to a final temperature of $650^{\circ} \mathrm{C}$. Data measured during pyrolysis include maximum temperature $\left(\mathrm{T}_{\max }\right)$ measured 
圆
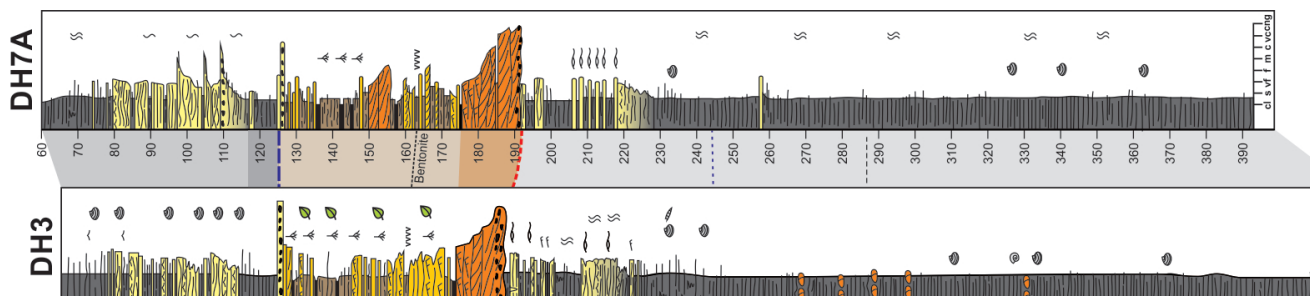

篦

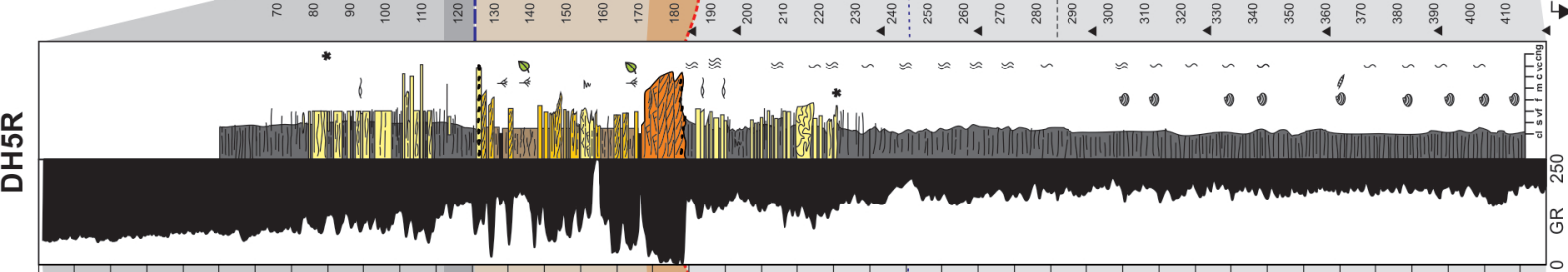

孛
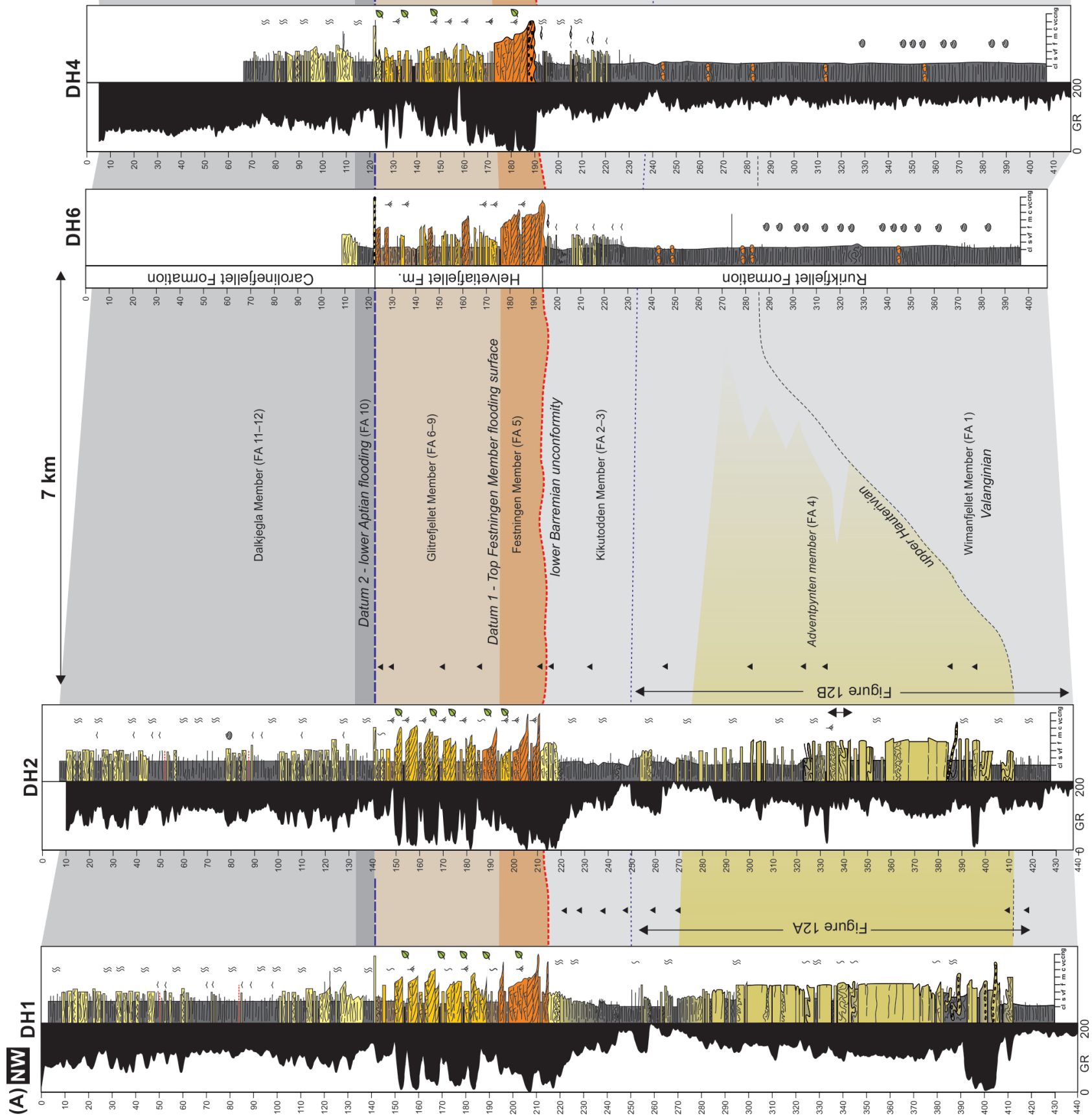
(B) Lithology:

\begin{tabular}{l}
\hline Offshore mudstone \\
\hline Marine sandstone \\
Fluvial sandstone \\
Overbank sandstone \\
Fluvial mudstone \\
Turbiditic sandstone \\
\hline$\square$ Sandstone/shale ratio \\
\hline Carbonate cement \\
Grain size: \\
cl clay \\
sl silt \\
vf very fine sand \\
f fine sand \\
m medium sand \\
c coarse sand \\
vc very coarse sand \\
cng conglomerate
\end{tabular}

Sedimentary structures:

\begin{tabular}{|c|c|}
\hline へ & Wave ripple \\
\hline$\pi$ & Current ripple \\
\hline & Plane parallel lamination \\
\hline 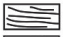 & -angle lamination \\
\hline & mocky cross-stratif \\
\hline & rat \\
\hline
\end{tabular}

Trace fossil symbols:

₹ Cruziana Ichnofacies

$\checkmark$ Skolithos Ichnofacies

$\mho$ Dinosaur footprint

A Rootlets

Degree of bioturbation:

sss High

ss Moderate

s Low

$\varnothing \quad$ Leaves

$\star$ Fossilised wood

$\therefore$ Rip-up clasts

$\odot$ Siderite nodule

* Glendonite

---F Fault plane

- Palynomorph sample
Trace fossils:

Ar Arenicolites

As Asterosoma

Au Aulichnites

Ch Chondrites

Di Diplocraterion habichi

He Helminthopsis

$\mathrm{Ne} \quad$ Nereites missouriensis

Op Ophiomorpha

Pa Palaeophycus

Ph Phycosiphon incertum

Pl Planolites

Ro Rosselia

Sc Schaubcylindrichnus

Sk Skolithos

Te Teichichnus

Th Thalassinoides

Zo Zoophycos

Figure 4. Correlation panel of wells (A; left). The accompanying legend (B) is also applicable to Figs. 5, 6, 11 and 12. The panel is corrected for structural dip and is flattened on the lower Aptian flooding surface separating the Helvetiafjellet and Carolinefjellet formations. The panel is oriented NW-SE and is therefore oriented parallel to the overall direction of depositional dip. Gamma-ray logs are included for wells DH1, DH2, DH4 and DH5R. Note the presence of the thick unit of gravity flow deposits in wells DH1 and DH2, here informally referred to as the Adventpynten member. The interval marked with a black arrow in the DH2 well represents a rafted block of coastal plain deposits. Note also the local thickness variation of the Festningen Member, indicating variable degrees of incision and possibly the presence of incised valleys. Black triangles indicate samples collected and analysed for biostratigraphy.

Table 2. Summary of Total Organic Carbon (TOC) and Rock-Eval pyrolysis in shale samples of restricted shelf origin (FA 10) in the DH1 and DH5R wells. Data from DH1 have been retrieved from Midtkandal et al. (2016). ${ }^{\star}$ Sample selected for GC-MS analysis.

\begin{tabular}{|c|c|c|c|c|c|c|c|c|c|}
\hline Well & Depth (m) & $\begin{array}{c}\text { TOC } \\
\text { (wt. \%) }\end{array}$ & $\begin{array}{c}\mathrm{S} 1 \\
(\mathrm{mg} / \mathrm{g})\end{array}$ & $\begin{array}{c}\mathrm{S} 2 \\
(\mathrm{mg} / \mathrm{g})\end{array}$ & $\begin{array}{c}\mathrm{S} 3 \\
(\mathrm{mg} / \mathrm{g})\end{array}$ & $\begin{array}{c}\text { HI (mg } \\
\text { HC/g } \\
\text { TOC) }\end{array}$ & $\begin{array}{l}\mathrm{OI}(\mathrm{mg} \\
\mathrm{CO}_{2} / \mathrm{g} \\
\mathrm{TOC})\end{array}$ & $\begin{array}{l}\mathrm{T}_{\max } \\
\left({ }^{\circ} \mathrm{C}\right)\end{array}$ & PI \\
\hline DH1 & 137.15 & 1.63 & 0.66 & 1.88 & 0.44 & 115 & 27 & 438 & 0.26 \\
\hline DH1 & 138.69 & 1.76 & 0.43 & 2.39 & 0.19 & 136 & 11 & 448 & 0.15 \\
\hline DH1 & 139.53 & 2.09 & 0.28 & 1.15 & 0.24 & 55 & 11 & 441 & 0.20 \\
\hline DH1 & 140.34 & 1.83 & 0.25 & 0.57 & 0.26 & 31 & 14 & 440 & 0.30 \\
\hline DH1 & 141.07 & 1.68 & 0.44 & 2.18 & 0.16 & 130 & 10 & 450 & 0.17 \\
\hline DH1 & 141.82 & 1.64 & 0.53 & 2.08 & 0.15 & 127 & 9 & 449 & 0.20 \\
\hline DH1 & 143.30 & 2.10 & 0.37 & 1.52 & 0.24 & 73 & 11 & 444 & 0.20 \\
\hline DH1 & 143.85 & 1.84 & 0.36 & 1.47 & 0.21 & 80 & 11 & 445 & 0.20 \\
\hline DH1 & 144.30 & 1.89 & 0.33 & 1.23 & 0.23 & 65 & 12 & 444 & 0.21 \\
\hline DH5R & 113.07 & 2.05 & 0.36 & 2.64 & - & 129 & - & 455 & 0.12 \\
\hline DH5R & 114.71 & 1.27 & 0.48 & 2.28 & - & 180 & - & 447 & 0.17 \\
\hline DH5R & 116.58 & 1.84 & 0.85 & 3.94 & - & 214 & - & 449 & 0.18 \\
\hline DH5R & 118.40 & 1.56 & 0.57 & 2.91 & - & 187 & - & 449 & 0.16 \\
\hline DH5R & $120.50^{*}$ & 1.99 & 0.65 & 3.77 & - & 189 & - & 451 & 0.15 \\
\hline
\end{tabular}

at the peak generation of hydrocarbons, $\mathrm{S}_{1}$ (the amount of free liquid hydrocarbons), $\mathrm{S}_{2}$ (potential amount of hydrocarbons to be generated), $\mathrm{S}_{3}$ (the amount of $\mathrm{CO}_{2}$ generated during pyrolysis), oxygen index (OI; data only available for well DH1) and hydrogen index (HI; Table 2). Calculated data include the production index $\left(\mathrm{PI} ; \mathrm{S}_{1} /\left(\mathrm{S}_{1}+\mathrm{S}_{2}\right)\right)$. Collectively, these parameters are used to assess the thermal maturity of the organic matter present in the samples, source-rock potential and kerogen type. Solvents from one sample from DH5R were further extracted, de-asphalted and fractionated before the saturated hydrocarbons were analysed by gas chromatography-mass spectrometry (GC-MS). The GC-MS data provide detailed information on the 


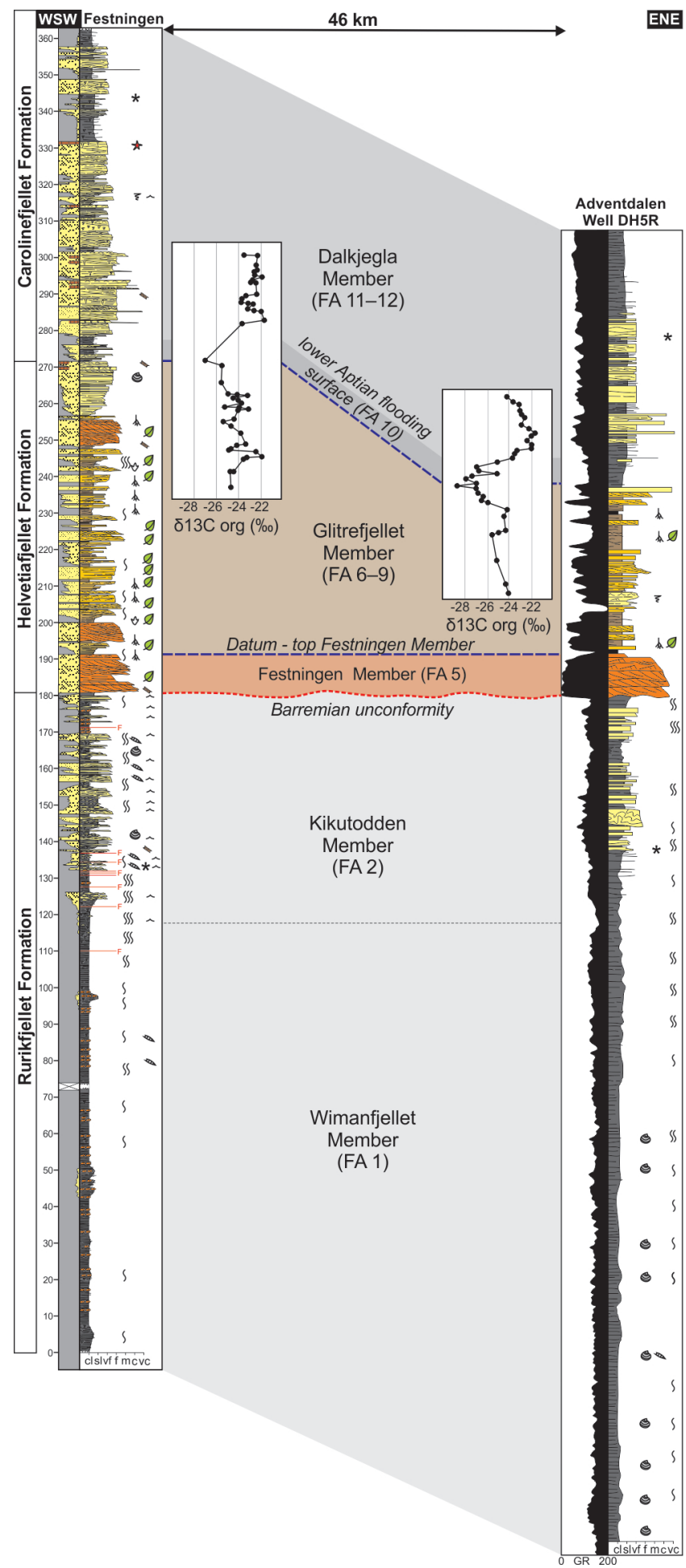

Figure 5. Correlation of the Festningen outcrop section with well $D H 5 R$, positioned $46 \mathrm{~km}$ apart. The panel is oriented WSW-ENE. The panel is corrected for structural dip and is flattened on a coaly shale horizon which caps the fluvial braidplain deposits of the Festningen Member. The coaly shale is interpreted to represent the proximal expression of a marine flooding surface, and in the Festningen section, the horizon is located between two vertically stacked channel bodies. Both the Festningen section and well DH5R record the stratigraphic development typical for the Lower Cretaceous succession elsewhere in Svalbard (e.g., Gjelberg \& Steel, 1995). However, note the thickness variation of the Glitrefjellet Member between the two sites. The correlation of the lower Aptian flooding surface is supported using $\delta^{13} C_{\text {org }}$ curves from Festningen (Vickers et al., 2016) and from well DH1 (Midtkandal et al., 2016). molecule content and the structure of organic compounds from the extract. The GC-MS analysis was conducted by ENI, Norway.

\section{Facies associations}

A total of 12 facies associations are recognised (FA 1-12; Table 1). Their characteristics and stratigraphic distribution within the three Lower Cretaceous formations are briefly summarised below.

\section{Facies associations of the Rurikfjellet Formation}

FAs 1-4 constitute the Rurikfjellet Formation (Fig. 4; Table 1). FA 1 is shale-dominated (Figs. 4 \& 7A-D) and volumetrically the most important association of the Rurikfjellet Formation with a thickness exceeding $200 \mathrm{~m}$ across the entire study area. Trace fossils and glendonites are variably present (Fig. 7B, C; Vickers et al., 2018). Deposition primarily took place below storm-wave base in a relatively shallow shelf environment below stormwave base (Dypvik et al., 1991b). FA 2 (Fig. 7E-H) is more heterolithic and rich in hummocky cross-stratified (HCS) sandstones, suggesting deposition in open marine, shallow shelf to nearshore environments above the storm-wave base (Dypvik et al., 1991b). Together, these associations form an overall regressive succession recording a long-term shoaling of the basin (Dypvik et al., 1991a; Midtkandal et al., 2008). The orientation of waveripple crests in FA 2 are widely scattered (Fig. 8A), but a WSW-ENE trend is evident in the western and northern parts of the study area, and a SSW-NNE to N-S trend dominates in the eastern part (Fig. 8A). Dip-azimuths of anisotropic HCS foresets are also widely scattered, but locally display strong modes towards the south and southeast (Fig. 8A). FA 3 consists of sandy mudstones that grade upwards into sandstones with abundant softsediment deformation structures (Fig. 9A-D). A prodelta slope to delta-front depositional environment is inferred for this facies association. FA 4 consists of thick-bedded, poorly sorted diamicts and sandstones with various gradings and chaotic fabrics (Fig. 9E-I). This facies association represents deposition from a wide range of mass flows in a lower slope to basin-floor setting. FAs 3 and 4 only occur in wells DH1 and DH2, and have not previously been documented in detail (only briefly by Braathen et al., 2012). Thus, thorough descriptions of these facies associations are provided later in the text.

\section{Facies associations of the Helvetiafjellet Formation}

FAs 5-9 constitute the Helvetiafjellet Formation (Fig. 4; Table 1) and broadly represent deposition in fluvial 


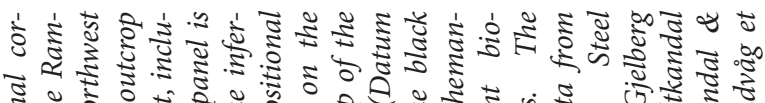

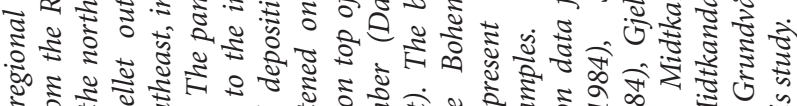

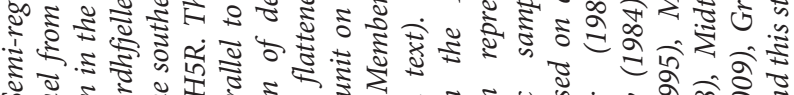

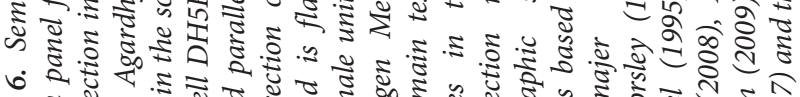

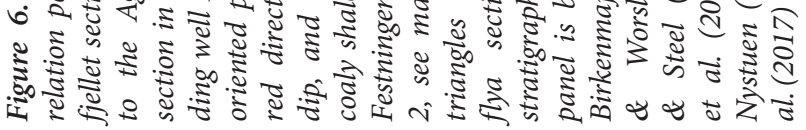

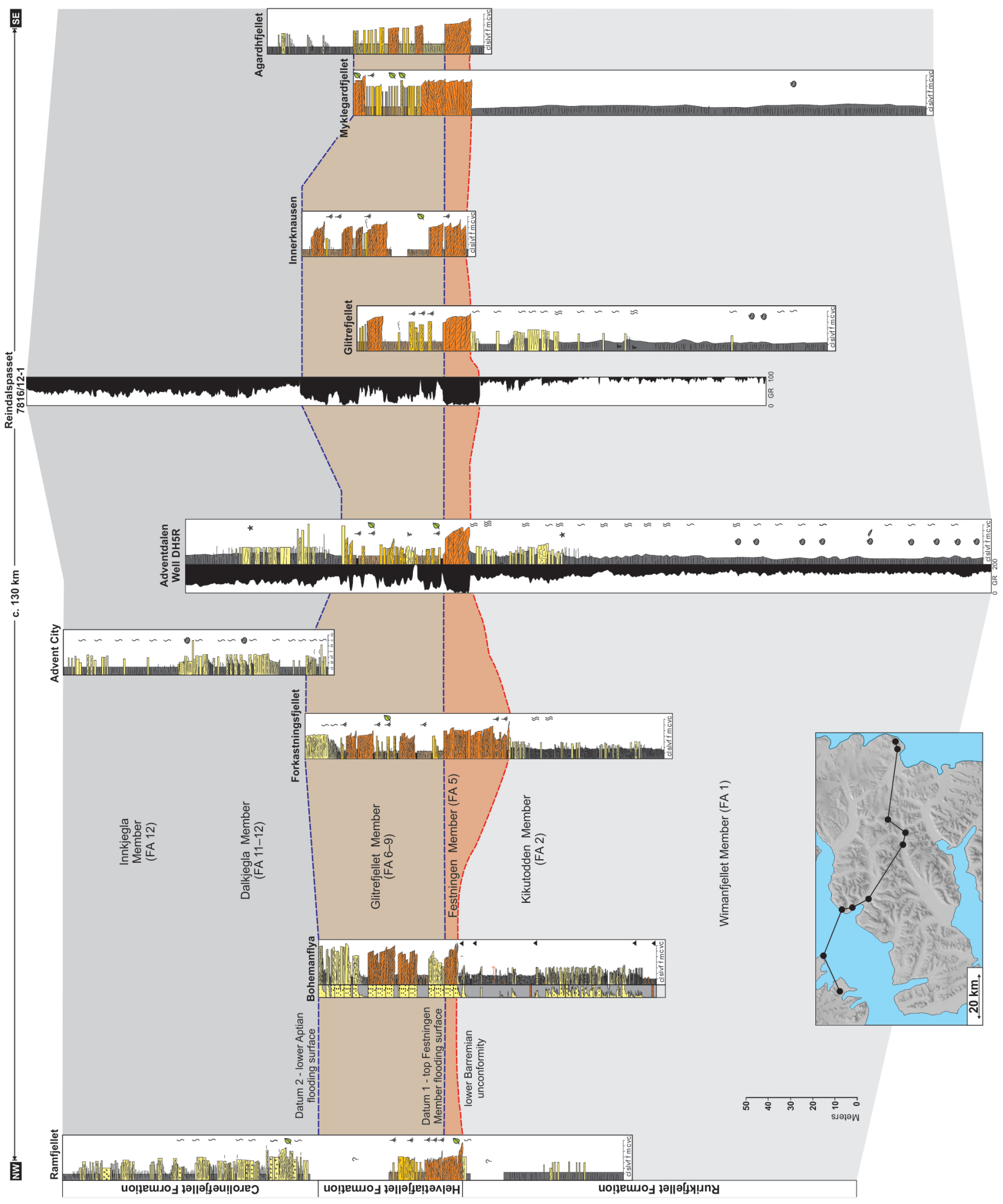



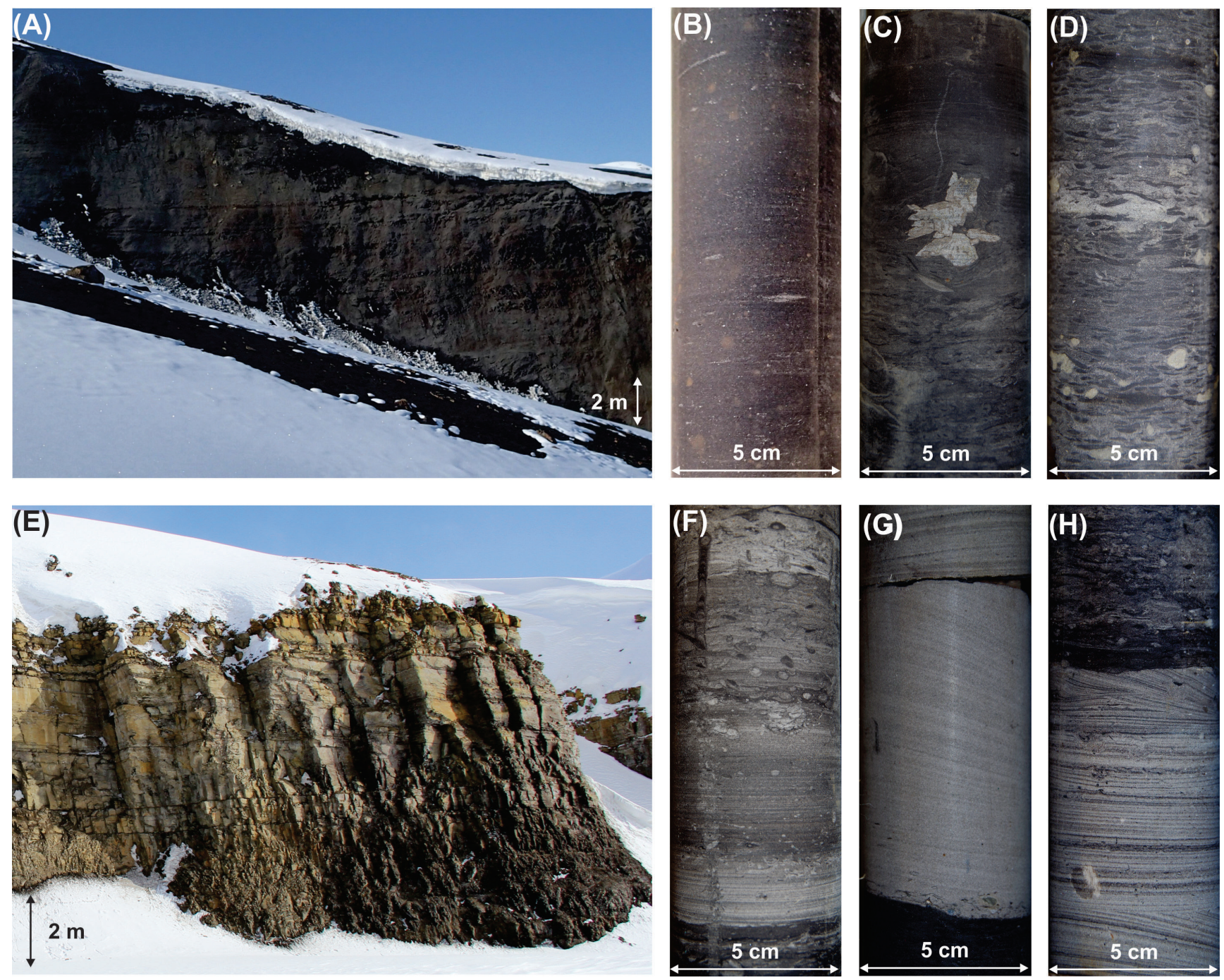

Figure 7. (A) Outcrop expression of FA 1 (offshore shelf) in the shale-dominated Wimanfjellet Member at the Helvetiafjellet locality (Fig. $1 C$ for location). (B) Core expression of dark, silty shale (well DH2). This is the dominant facies within the Wimanfjellet Member. (C) Glendonites occur sporadically throughout the unit (well DH5). (D) Bioturbated sandy siltstones typically occur in the upper part of the Wimanfjellet Member and indicate well-oxygenated conditions on the shelf (well DH6). (E) Outcrop expression of FA 2 (offshore transition to lower shoreface) forming a shoaling-upward parasequence in the Kikutodden Member in Mälardalen (Fig. 1C for location). The lower parts of these parasequences consist of heterolithic intervals of thin-bedded sandstones alternating with bioturbated mudstones and siltstones (F; well $D H 5 R)$. Hummocky cross-stratified beds ( $G$; well DH4), commonly with wave-rippled tops (H; well DH4), typically occur in the upper part of the parasequences and record deposition during and following storms.

(continental) to paralic environments, conforming to previous interpretations (e.g., Steel et al., 1978; Nemec et al., 1992; Gjelberg \& Steel, 1995; Midtkandal et al., 2007). FA 5 consists of coarse-grained and crossstratified sandstones attributed to deposition in a fluvial braidplain environment (Fig. 10A-D). The facies association comprises the Festningen Member (e.g., Nemec, 1992; Midtkandal et al., 2007). Dip-azimuths of the cross-stratification foresets indicate south to southeast-directed sediment dispersal (Fig. 8B; Nemec, 1992; Gjelberg \& Steel, 1995). FA 6 consists primarily of mudstones which locally contain rootlets and thinly interbedded coals, suggesting deposition mainly in floodplain and interdistributary bay environments (Fig. 10E, F). FA 7 typically alternates with FA 6, and consists of sheet-like, generally upward-coarsening, sandstone bodies representing crevasse splay deposits (Fig. 10E, G, \& H; Steel et al., 1978). FAs 6 and 7 make up the bulk of the Glitrefjellet Member (Fig. 4; Steel et al., 1978; Nemec, 1992; Midtkandal et al., 2007). FA 8 has previously been widely described in outcrops and consists of up to $12 \mathrm{~m}$-thick sandstone units which typically exhibit coarsening- and thickening-upwards trends, and locally display wave-ripple cross-lamination and large-scale foresets (e.g., Gjelberg \& Steel, 1995). This suggests deposition by prograding delta lobes in shallow water depths (Nemec, 1992; Gjelberg \& Steel, 1995; Steel et al., 2000; Midtkandal et al., 2007). In the wells, FA 8 occurs as a $<5$ m-thick, heavily wavereworked unit which includes a 10-40 cm-thick, 

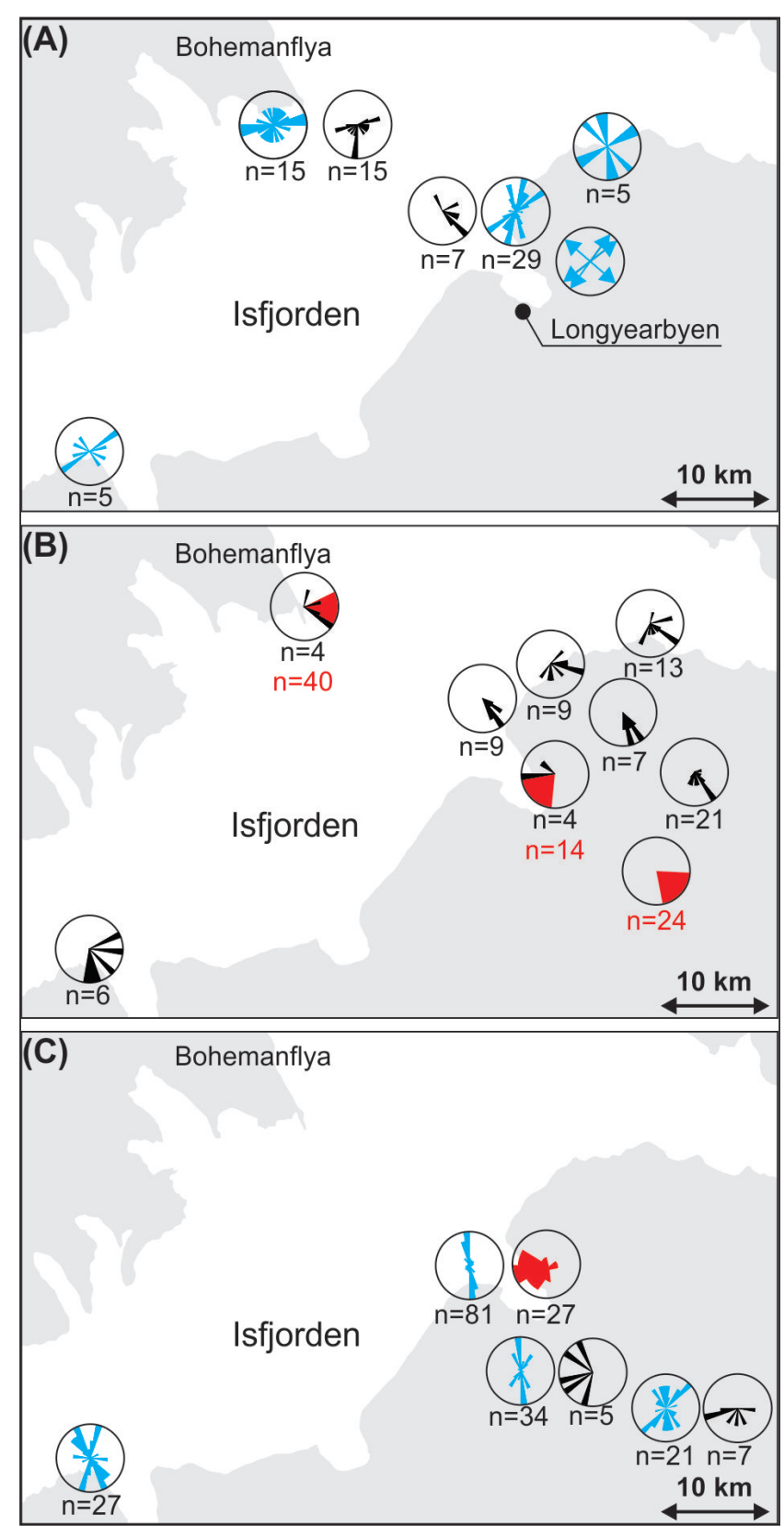

Figure 8. Palaeocurrent directions for the Rurikfjellet (A), Helvetiafjellet (B) and Carolinefjellet (C) formations in the study area. The results are discussed thoroughly in the main text. (A) The blue rose diagrams and arrows indicate wave-ripple crest orientations, and the black represent the migration direction of anisotropic hummocky cross-stratification. (B) The black rose diagrams represent the dip-azimuths of foresets measured in cross-stratified sandstones within the Festningen Member (FA 5, braidplain deposits). The red rose diagrams represent measurements obtained from Gjelberg \& Steel (1995). (C) The blue rose diagrams indicate wave-ripple crest orientations, whereas the black represent the migration direction of anisotropic hummocky cross-stratification. The red rose diagram represents the migration direction of anisotropic hummocky cross-stratification obtained from Nøttvedt \& Kreisa (1987). sharp-based, lithic and siderite-bearing conglomerate bed immediately below the basal shale unit (FA 10) of the overlying Carolinefjellet Formation (Figs. 4, 11; Tennvassås, 2018). Due to the presence of the conglomerate, a thorough description of the subsurface expression of the associated delta front (FA 8) deposits is provided later in the text. FA 9 consists of vague, fining-upwards, cross-bedded sandstone units up to $5 \mathrm{~m}$ thick with concave-up bases incising into the underlying and surrounding deposits of FAs 6-8 (Fig. 4). This association represents deposition in fluvial distributary channels (Steel et al. 1978; Nemec, 1992; Gjelberg \& Steel, 1995). Double mud drapes occur locally (e.g., in well DH5R), suggesting a tidal influence in some of the channels.

\section{Facies associations of the Carolinefjellet Formation}

The Carolinefjellet Formation resembles the Rurikfjellet Formation in terms of the abundance of HCS sandstones and the inferred storm-influenced, open-marine shelf, depositional environment (Table 1). However, due to the high content of volcanically derived sediments (Maher et al., 2004), the generally higher content of sandstones, increased bed thickness and degree of amalgamation, as well as the difference in trace fossil assemblage (Table 1), the deposits of the Carolinefjellet Formation are given separate FA codes (FAs 10-12; Fig. 4; Table 1). FA 10 consists of an up to $10 \mathrm{~m}$-thick, dark grey to black, organic-rich (sapropelic) shale-unit of regional extent (Figs. 4, 5, 6 \& 11). The association was deposited in a restricted shelf setting during a major flooding (Midtkandal et al., 2016). Because this unit has not previously been described in detail, a detailed description is provided later in the text. FA 11 consists of up to 15 m-thick, tabular-shaped, sandstone units dominated by amalgamated HCS, which make up the bulk of the strata of the Dalkjegla Member (Fig. 10I-M; Nagy, 1970). Deposition took place in a storm-dominated and tidally influenced (cf., Birkenmajer, 1966) offshore transition to lower shoreface setting. Coarse-grained sandstones exhibiting trough cross-bedding occur at Festningen and at Ramfjellet in the western and northwestern parts of the study area, respectively (Figs. $5 \&$ 6). Thus, these sections are attributed to deposition in more shoreproximal settings (e.g., middle to upper shoreface). Wave ripple crests in FA 11 display N-S to NNE-SSW orientations (Fig. 8C), and foresets of anisotropic HCS are broadly oriented perpendicular to the wave ripple crests (Fig. 8C). Throughout the study area, FA 11 grades upwards into lenticular to wavy-bedded sandstones and interbedded mudstones of FA 12 to form a $150 \mathrm{~m}$ thick shale-dominated succession of the Innkjegla Member (Fig. 4; Nagy, 1970; Maher et al., 2004). FA 12 was deposited in storm-dominated, open-marine shelf environments (Table 1). 

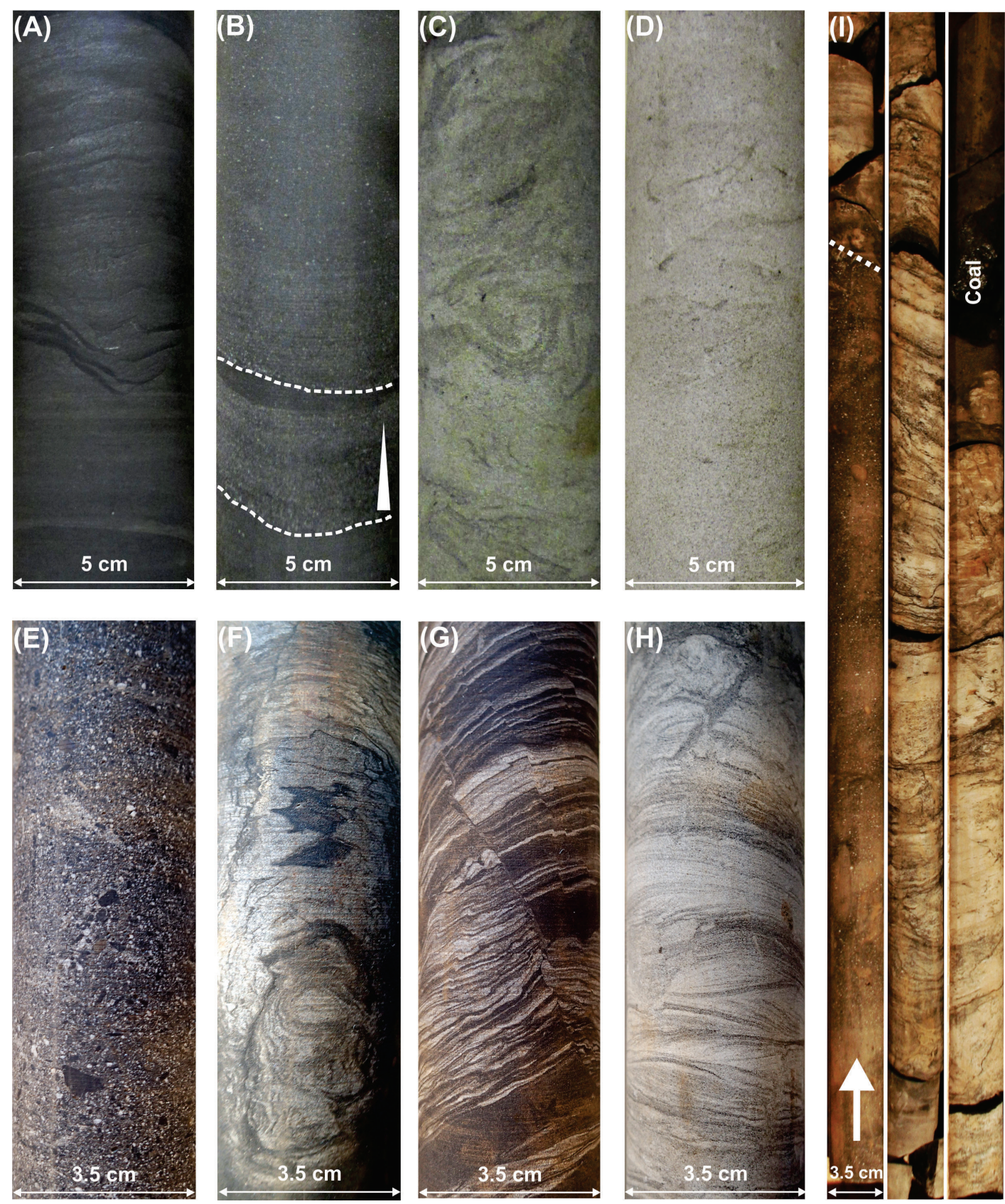

Figure 9. Core expression of FA 3 (prodelta slope to delta front; A-D, well DH2) and FA 4 (base-of-slope mass-transport complex; E-I, well DH1) in the Rurikfjellet Formation. These facies associations have not been reported from any outcrop-based studies. (A) Poorly sorted, sandy mudstones with inclined and distorted lamination characterise the prodelta slope deposits of FA 3. (B) Sharp-based, normally graded mudstone beds occur in places, and indicate deposition from low-density turbidity currents. The prodelta slope deposits grade upward into delta-front deposits consisting of soft-sediment-deformed sandstones $(C)$ and massive to bioturbated sandstone beds (D). Poorly sorted, sandy and mud-rich diamicts (E) dominate the base-of-slope mass-transport complex (FA 4). Soft-sediment deformed sandstones (F), folded and faulted heterolithic units $(G)$, and cleaner sandstones with current-ripple cross-lamination $(H)$ occur commonly. (I) Slump block in well DH2 (337-334 m; see Fig. 12C for sedimentological log). The block consists of sand-rich, heterolithic coastal-plain deposits, and includes rootlets and a coal horizon at its top. The arrow indicates stratigraphic up, and the dashed line marks the base of the slump block.

\section{New subsurface observations}

Sedimentary characteristics of FA 3 (prodelta slope to delta front) and FA 4 (base-of-slope mass-transport complex) in the Rurikfjellet Formation, the sideritecontaining conglomerate locally occurring in FA 8 (delta front) of the Helvetiafjellet Formation, as well as FA 10 (restricted shelf) of the Carolinefjellet Formation (Table 1) have not previously been described in detail. Detailed descriptions and interpretations of these units are thus given here. 

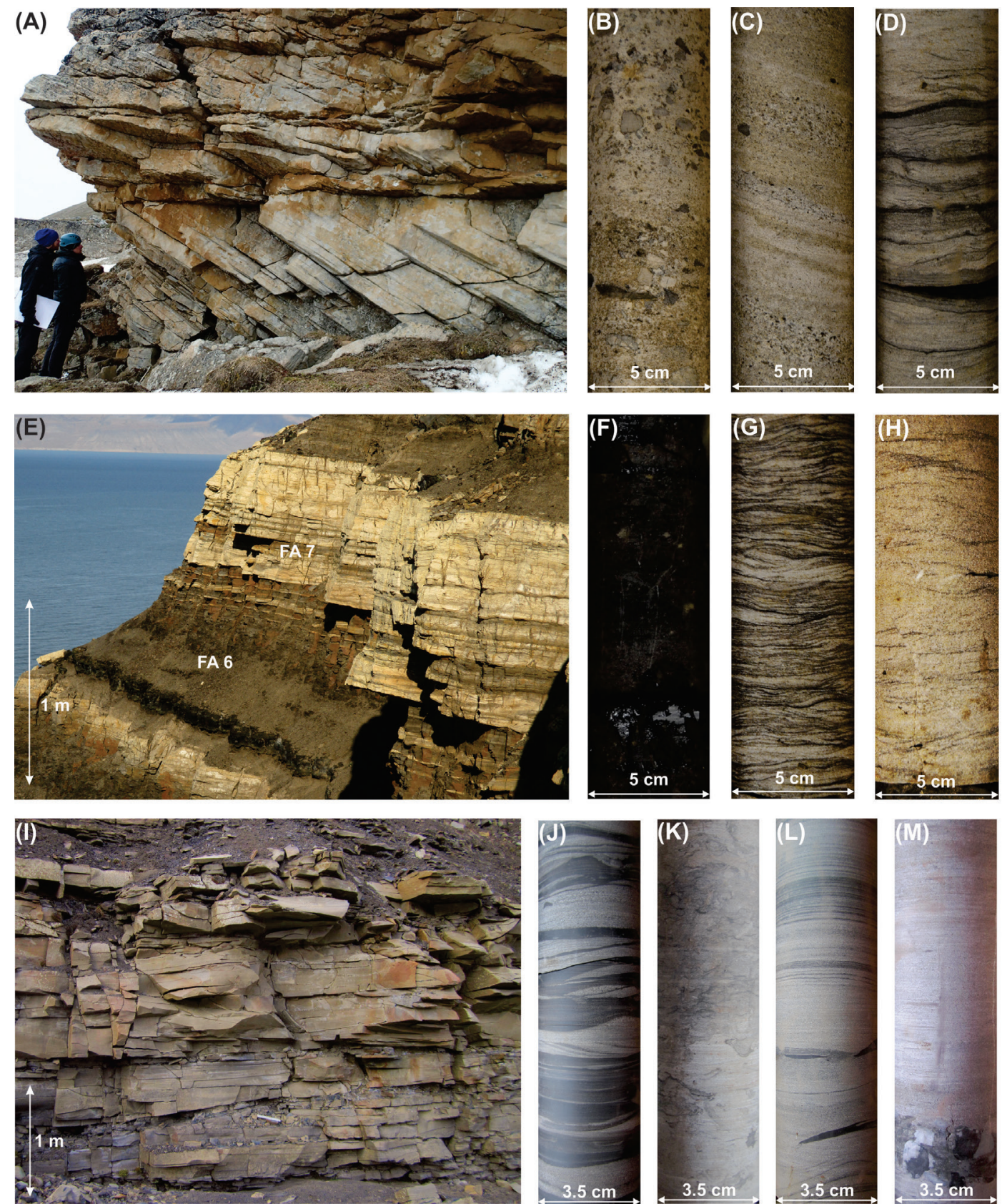

Figure 10. Outcrop and core expression of the Helvetiafjellet and Carolinefjellet formations. (A) Cross-stratified fluvial sandstones of the Festningen Member (FA 5, fluvial braidplain deposits) in Hanaskogdalen (Fig. 1C for location). Persons (c. $1.70 \mathrm{~m})$ for scale. The fluvial sandstone bodies commonly contain lags of lithic conglomerates (B; well DH6) and various dune-scale cross-strata (C; well DH6), as well as fine-grained heterolithic units with current-ripple cross-lamination (D, well DH5R) in their upper part. (E) The floodplain and interdistributary bay deposits (FA 6) are typically fine-grained, contain thin coals (F, well DH6), and alternate with crevasse splay sandstones (FA 7). Outcrop example from Forkastningsfjellet. FA 7 exhibits sheet-like geometries, and forms coarsening-and thickening-upward units with heterolithic lower parts $(G$, well DH5R) and abundant current-ripple cross-lamination (H, well DH6). (I) Thick-bedded and amalgamated hummocky cross-stratified sandstone units occur quite commonly in the Carolinefjellet Formation (FA 11). Lenticular-bedded sandstones with wave- or combined flow-ripple cross-lamination (J), bioturbated sandstones (K), plane-parallel lamination $(L)$, and HCS sandstone beds with lags of lithic conglomerate $(M)$ indicate deposition on a storm-dominated open-marine shelf. The core photos in J-M are from well DH7A.

\section{FA 3. Prodelta slope to delta front}

\section{Description}

This facies association occurs only in boreholes DH1 and DH2 and transitionally overlies FA 4 (base-of-slope mass-transport complex; Fig. 4). It consists of a 30-40 $\mathrm{m}$-thick mudstone-dominated unit (260-230 $\mathrm{m}$ in DH1;
Fig. 4). The mudstones are sand-rich, poorly sorted, and normally graded with inclined and distorted bedding (Fig. 9A). Interbeds of erosionally-based, normally graded, fine-grained sandstones to siltstones occur (Fig. 9B). The sandstone content increases upwards in concert with a gamma-ray decrease (Fig. 4). Soft-sediment deformation structures (Fig. 9C), current ripple cross- 
(A) Depth Natural gamma (m) (cps)

DH1

S-velocity $(\mathrm{m} / \mathrm{s})$ P-velocity $(\mathrm{m} / \mathrm{s})$

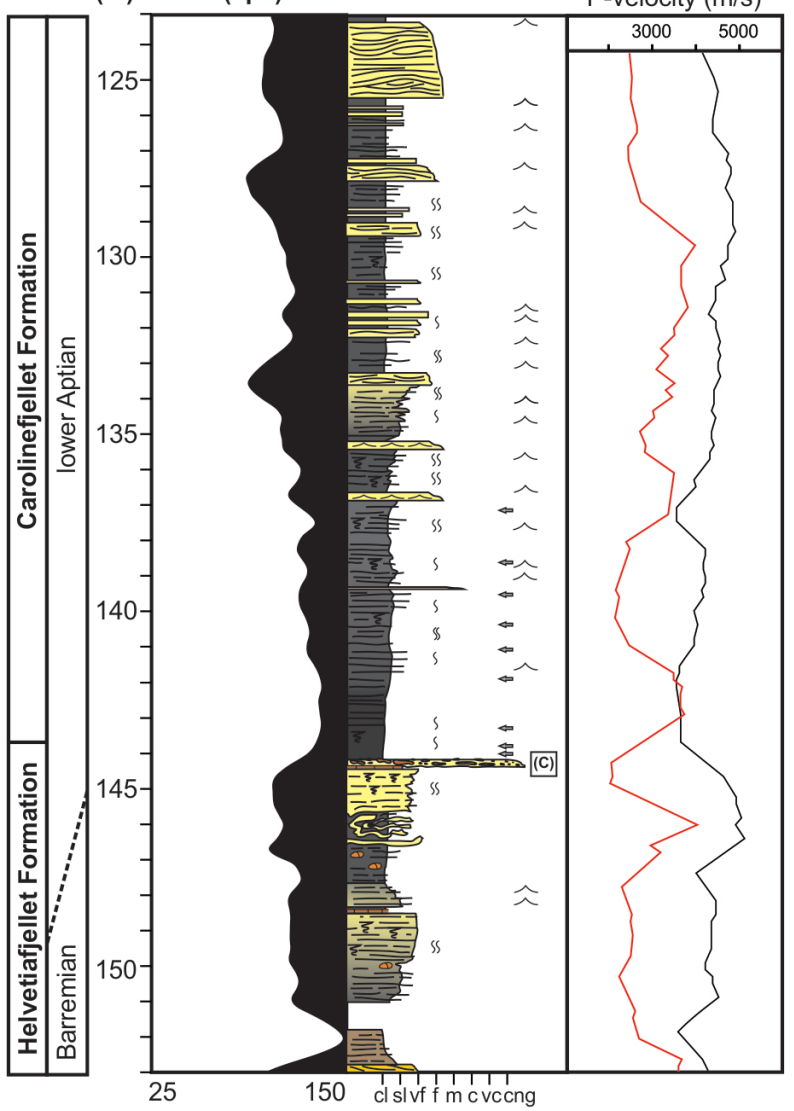

(B) Depth Natural gamma $\quad$ DH5R S-velocity $(\mathrm{m} / \mathrm{s}) \quad$ Interpretation

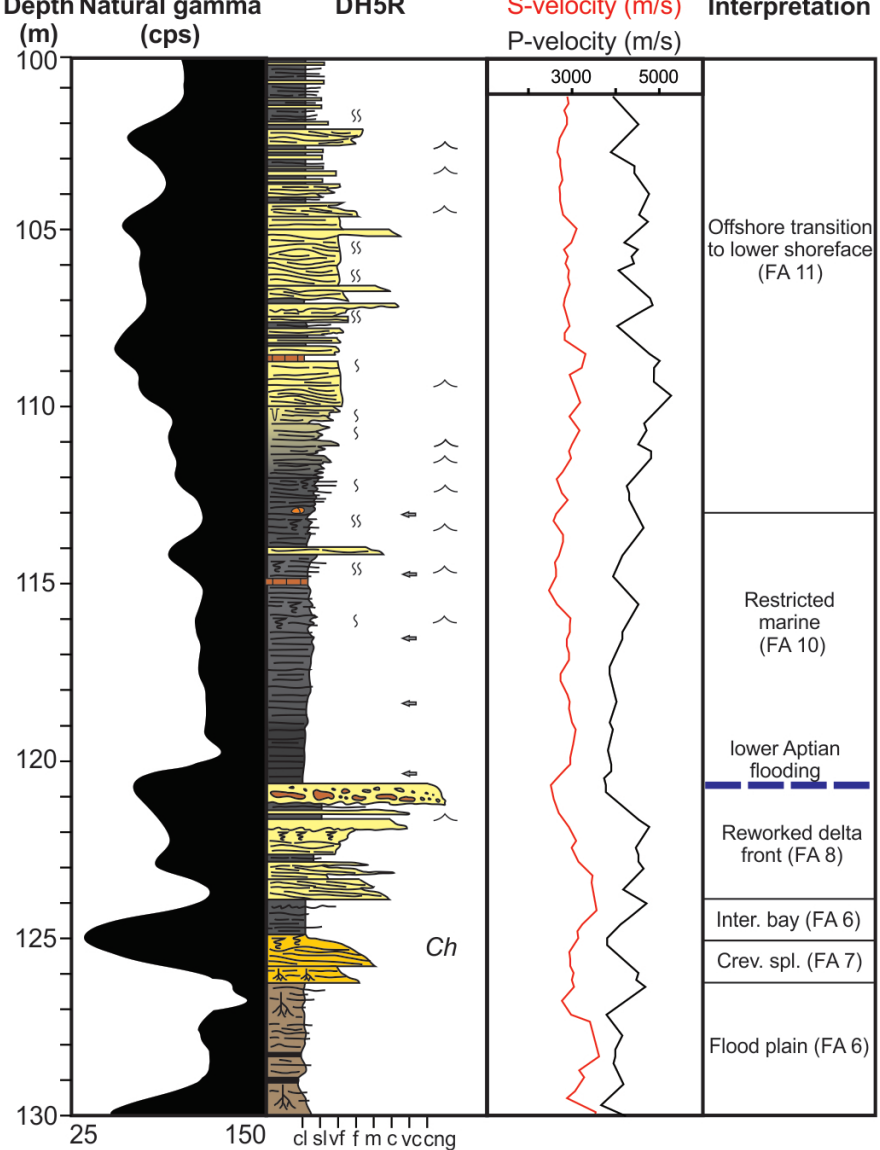

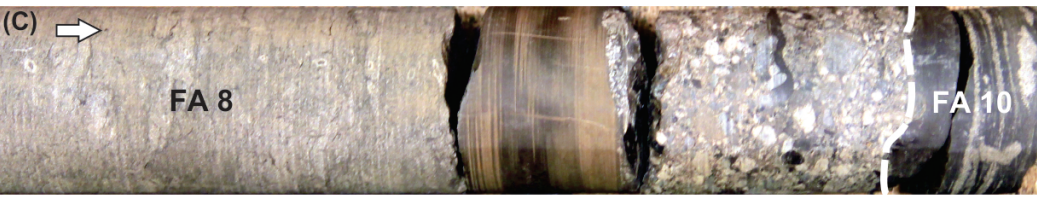
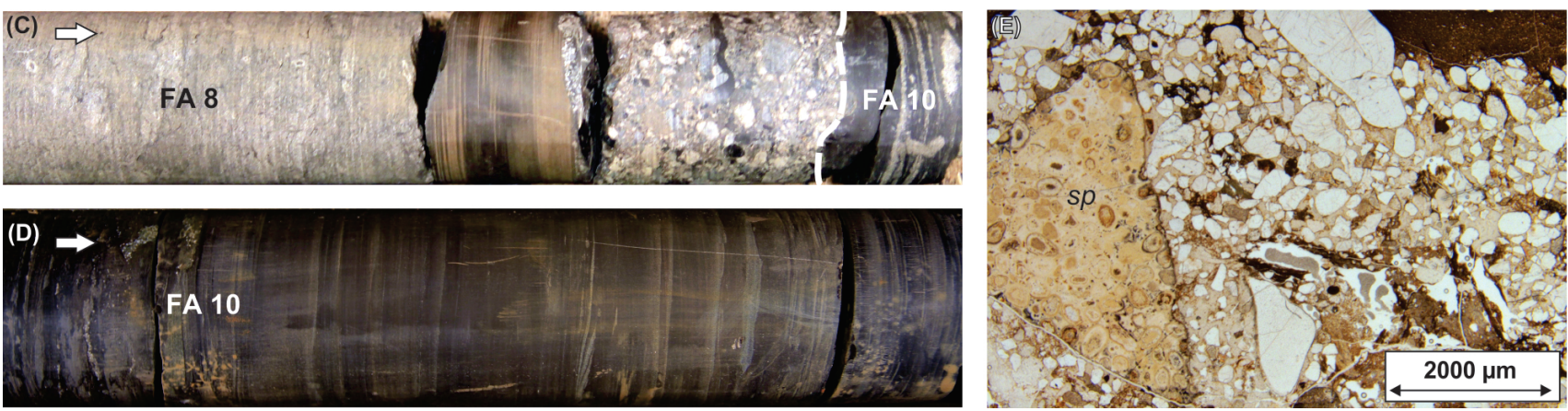

Figure 11. Detailed sedimentological logs across the boundary between the Helvetiafjellet and Carolinefjellet formations in the DH1 (A) and DH5R (B) wells showing a sapropelic shale unit (FA 10) overlying a transgressive conglomerate lag and a wave-reworked delta-front unit (FA 8). The shale is of a restricted shelf origin and grades upwards into offshore transition and lower shoreface deposits (FA 11). The grey arrows represent samples analysed for source-rock potential (Table 2; Figs. 13 \& 14). (C) Core photo of the conglomerate in DH1 (position marked by black box in A). Note the sharp erosive base and the abrupt upward facies change into FA 10. The core is $5 \mathrm{~cm}$ wide and the white arrow marks stratigraphic up. (D) Core photo of the organic-rich shale unit (FA 10) in well DH6. The core is $8 \mathrm{~cm}$ wide and the white arrow marks stratigraphic up. (E) Microscope photograph of the transgressive conglomerate showing its poorly sorted character. Note the presence of a spiculite clast (sp) originating from the Upper Permian Tempelfjorden Group.

lamination, and massive to bioturbated sandstone beds are variably present (Fig. 9D). The bioturbation index ranges from $0-1$ in the mudstones and increases up to 2 in the sandstones. Trace fossils include Phycosiphon incertum, Planolites, Palaeophycus and Thalassinoides.

\section{Interpretation}

Based on the frequent occurrence of inclined and distorted mudstones, as well as their sandy texture, this facies association is attributed to deposition in a prodelta slope environment dominated by gravity-flow processes. The coarsening-upwards trend indicates progradation and a transition into a lower deltafront environment dominated by traction and marine flood-related processes. The poorly sorted mudstones indicate gravity-flow deposition by various processes including suspension settling, rapid deposition from river-fed hyperpycnal flows (Mulder \& Syvitski, 1995; Bhattacharya \& MacEachern, 2009), turbidity currents initiated by rapid collapse of hypopycnal mud plumes 
(Parsons et al., 2001), and by offshore flushing of fluid mud during river floods (Neil \& Allison, 2005). The sharp-based normally graded beds suggest deposition from flood-generated turbidity and hyperpycnal flows (Bhattacharya \& MacEachern, 2009). Soft-sediment deformation structures may indicate slope failure and mass movement, or loading in combination with liquidisation processes. The low-diversity trace fossil assemblage resembles an impoverished Zoophycos Ichnofacies, reflecting stressed conditions with fluctuating salinity, turbidity and depositional rates (e.g., MacEachern et al., 2007).

\section{FA 4. Base-of-slope mass-transport complex}

\section{Description}

This facies association occurs only in boreholes DH1 and DH2, forming a more than $130 \mathrm{~m}$ thick succession of poorly sorted diamictites. The diamictites are composed of matrix-supported, sandy, dark-coloured mudstones with subrounded intraclasts consisting of sandy granules and claystone (Figs. 4, 9E-F \& 12). Better sorted sandstone divisions (evident by low gamma-ray values) and heterolithic units of thin-bedded sandstones and interbedded mudstones occur (Figs. 9G-H \& 12). Individual diamict beds are $0.1-4.5 \mathrm{~m}$ thick and have sharp erosive, or less frequently, loaded bases. They are typically characterised by a chaotic fabric with pervasive soft-sediment deformation structures, but commonly exhibit coarse-tail inverse to coarse-tail normal grading. Micro-faults with a few centimetre offsets (Fig. 9G), sand-filled fractures resembling small-scale injectites, distorted bedding, and folded heterolithic units occur frequently. The lower part of the succession is dominated by lithic conglomerates and interbedded bioturbated siltstones. The better sorted sandstones display planeparallel lamination and current ripple cross-lamination (Fig. 9H). The upper part of this association gradually fines and grades upwards into the overlying prodelta slope deposits (FA 3; Figs. 4 \& 12). In borehole DH2, a $1.6 \mathrm{~m}$-thick, strongly inclined, sharp-based coarseningupwards unit is observed (Figs. 9I \& 12C). It consists of very fine- to medium-grained sandstones with rootlets and a coal cap (Figs. 9I \& 12C). Bioturbation is absent in the sandstones, but the bioturbation index ranges from 3 to 4 in the interbedded fines. Typical trace fossils include Planolites, Phycosiphon incertum and Chondrites. Rare Palaeophycus and Schaubcylindrichnus freyi also occur.

\section{Interpretation}

The chaotic fabric, abundance of soft-sediment deformation structures, the poorly sorted character of the sandstones, and the presence of inversely graded beds rich in mudstone clasts and lithic conglomerates, suggest deposition from slumps and debris flows. Normally graded and current-ripple cross-laminated sandstone beds record deposition from surge-type, decelerating turbidity currents (e.g., Bouma, 1962). Thicker, ungraded, massive beds are interpreted to represent rapid deposition from collapsing high-density turbidity flows (Lowe, 1982), continuous aggradation from sustained, depletive turbidity flows (Kneller \& Branney, 1995), or alternatively as deposition from sandy debris flows (Shanmugam, 1996). The trace fossil assemblage resembles the Zoophycos Ichnofacies, largely representing shelf to slope-transitional environments (e.g., MacEachern et al., 2007). The 1.6 m-thick, inclined, sharp-based, coarsening-upwards coal-bearing unit in $\mathrm{DH} 2$, is interpreted to be a slumped block of delta-plain origin. Based on its stratigraphic position below prodelta slope deposits (FA 3), and the dominance of gravity-flow deposits, FA 4 is interpreted to represent a mass-transport complex which accumulated in a lower slope to basin floor setting prior to delta progradation into the study area.

\section{FA 8. Delta-front deposits}

\section{Description}

In order to provide stratigraphic context for the sideritebearing lithic conglomerate below the basal shale unit of the Carolinefjellet Formation (FA 10), the subsurface expression of the delta-front deposits immediately below the conglomerate is described here (Fig. 11). In outcrops, this facies association forms tabular to wedgeshaped sandstone bodies up to $12 \mathrm{~m}$ thick, internally displaying coarsening-upwards trends and clinoform geometries at the scale of a few to ten metres (Nemec, 1992; Gjelberg \& Steel, 1995; Midtkandal et al., 2007). In the wells, this facies association is up to $6 \mathrm{~m}$ thick and consists of lenticular-bedded, very fine- to fine-grained sandstones alternating with thin mudstones (Fig. 11). Medium- to coarse-grained sandstone beds up to $10 \mathrm{~cm}$ thick occur sporadically. This facies association typically overlies mudstones of FA 6 with the sandstone content and bed thickness gradually increasing upwards to form a vague coarsening-upwards unit in the uppermost part of the Helvetiafjellet Formation in the wells (Figs. 4 $\&$ 11). Current-ripple cross-lamination, wave-ripple lamination, plane-parallel lamination, low-angle crossstratification, and soft-sediment deformation structures occur (Fig. 11). Siderite concretions are present locally. Trace fossils are variably present (bioturbation index of 0-5) and include dominant Schaubcylindrichnus freyi and subordinate Chondrites and Planolites. The facies association is capped by a $10-40 \mathrm{~cm}$-thick, sharp-based conglomerate bed (Fig. 11A-C). The conglomerate is poorly sorted and consists of a medium- to coarsegrained quartz-rich sandy matrix with variable contents of larger extrabasinal lithic clasts and intraformational siderite clasts (Fig. 11C). Thin section analysis of the conglomerate in well DH1 reveals the presence of rounded spiculite clasts originating from the Upper Permian Tempelfjorden Group (Fig. 11E). Low-angle stratification occurs in places. 


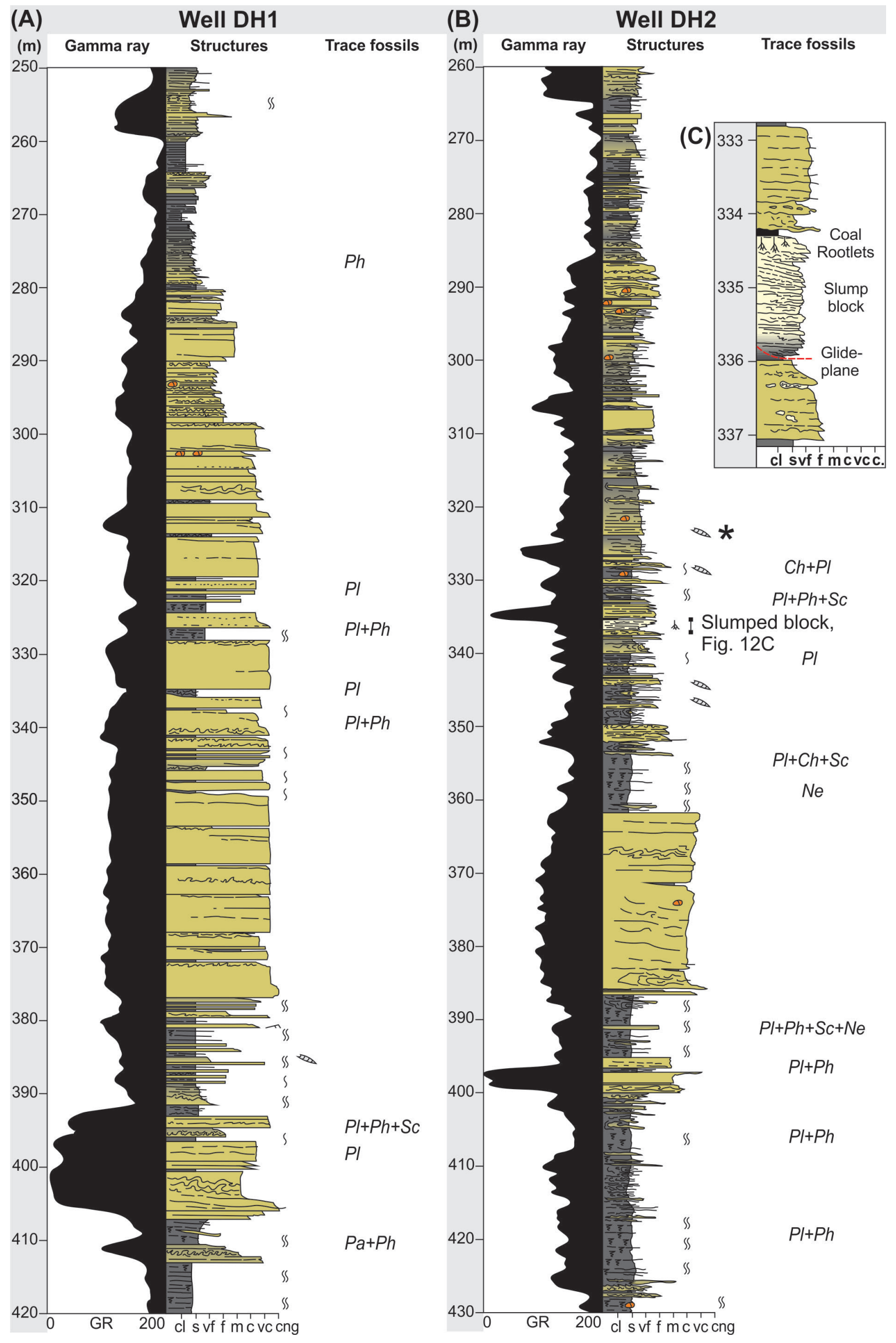

Figure 12. Detailed sedimentological logs of FA 4 (base-of-slope mass transport complex; Table 1) in wells DH1 (A) and DH2 (B). Note the presence of a rafted slump block in well DH2 (marked with black bar and denoted 'Slumped block'). The slump block is shown in detail in (C). The sandstones in the coastal plain slump block are cleaner and better sorted than the surrounding gravity-flow deposits as indicated by a low gamma-ray response. 


\section{Interpretation}

Based on the overall coarsening- and thickeningupwards trend, its stratigraphic position above mudstones of FA 6 (floodplain to interdistributary bay deposits), and the occurrence of traction-generated structures, this facies association is attributed to deposition by prograding delta lobes (e.g., Nemec, 1992; Gjelberg \& Steel, 1995). The occurrence of wave-ripple cross-lamination and low-angle cross-stratification (possibly representing hummocky cross-stratification) indicates wave and storm-wave reworking of the delta front. Siderite and intensely bioturbated beds reflect periods of non-deposition. The conglomerate bed capping the delta front deposits is interpreted to be a lag deposit formed by transgressive ravinement during the final flooding of the Helvetiafjellet Formation coastal plain. The presence of the overlying regional extensive shale unit of FA 10 (restricted shelf deposits; Table 1) support a transgressive origin for the conglomerate.
(A)
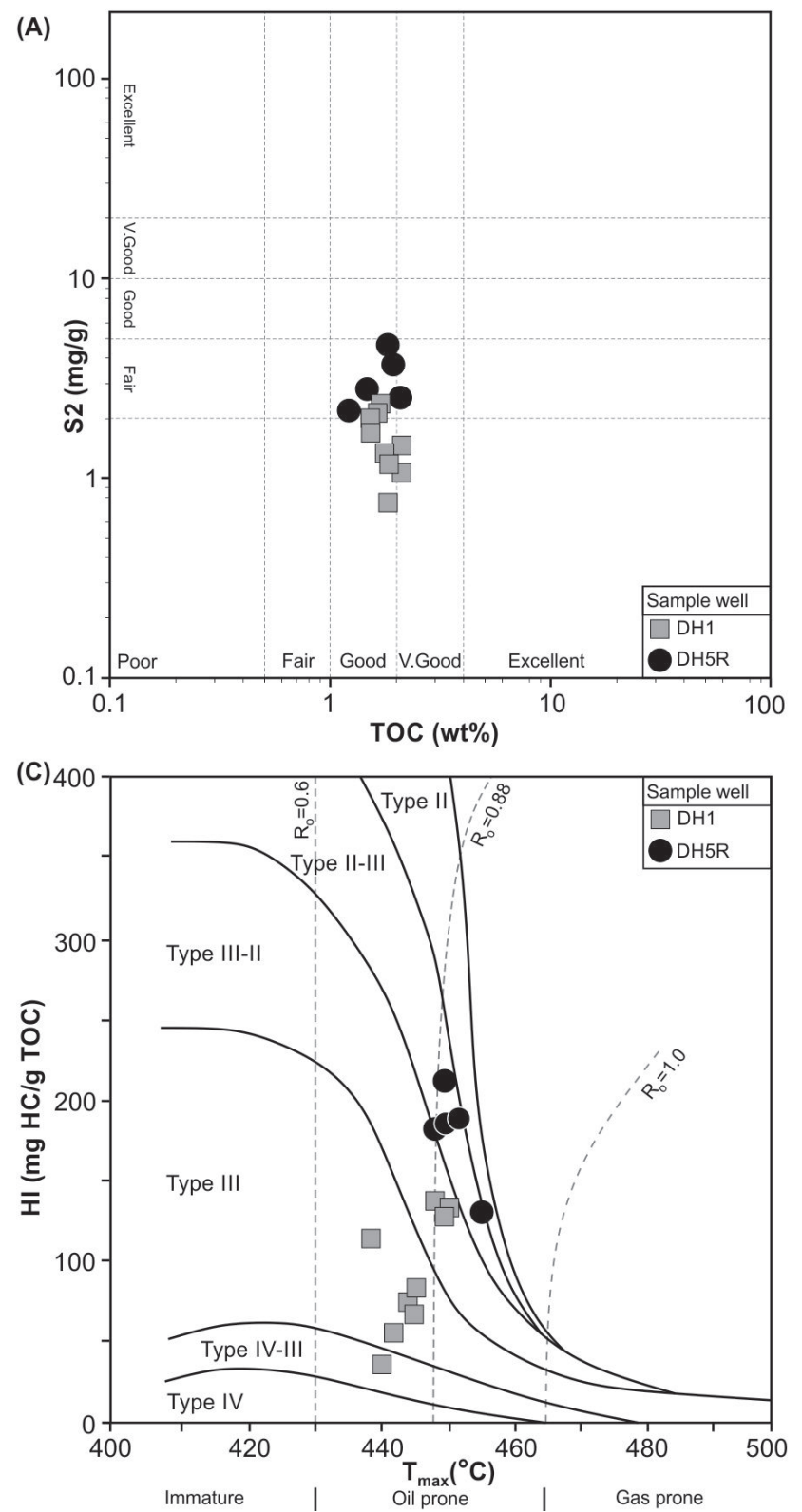

(B)
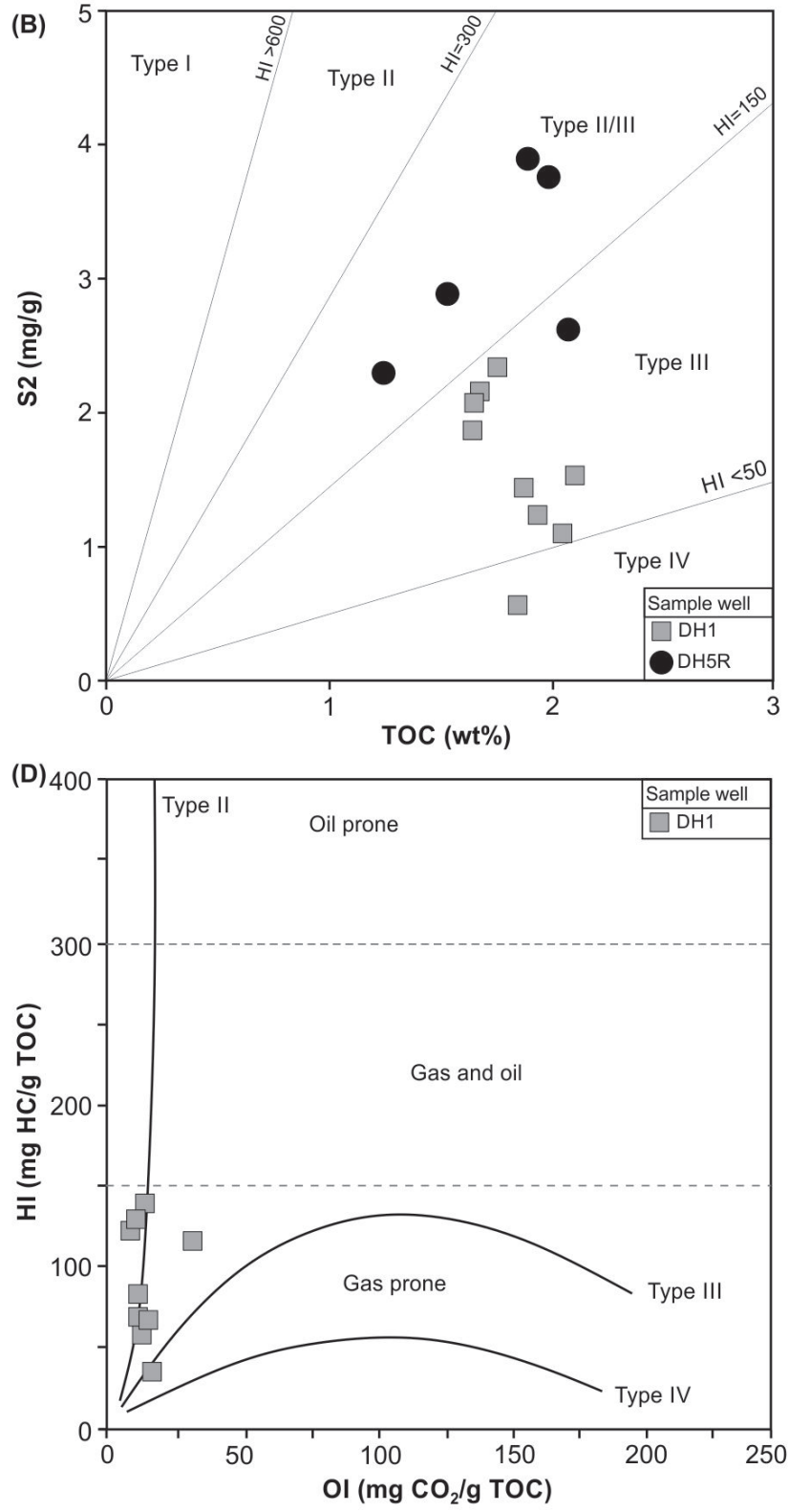

Figure 13. Plots showing the source-rock potential of the shale unit (FA 10) separating the Helvetiafjellet and Carolinefjellet formations in wells DH1 and DH5R. The Total Organic Carbon (TOC) and Rock-Eval data are shown in Table 2. (A) Cross-plot of TOC vs. $S_{2}$ indicating variations in organic matter enrichment (i.e., richness) ranging from poor to excellent (based on Peters \& Cassa, 1994). (B) Cross-plot of TOC vs. Rock-Eval $S_{2}$ together with selected hydrogen index (HI) values indicating kerogen type. (C) Plot of $T_{\max }$ vs. HI showing the petroleum potential and thermal maturity of the samples. Iso-vitrinite reflectance (Ro) lines (based on coal) according to Isaksen \& Ledje (2001). (D) Van Krevelen diagram of HI plotted against oxygen index (OI) showing the quality and maturation level of the samples from well DH5R. 


\section{FA 10. Restricted shelf deposits}

\section{Description}

This facies association is poorly exposed in most outcrops. Thus, the following description is primarily based on core observations. FA 10 occurs across the entire study area as an up to $10 \mathrm{~m}$-thick, dark grey to black, finely-laminated, organic-rich (TOC up to 2.1 wt.\%; Table 2) shale unit in the lowermost part of the Carolinefjellet Formation (Table 1; Figs. 4, 5, 6 \&11). In all the $\mathrm{CO}_{2}$-wells, the shale caps a sharp-based lithic conglomerate unit (FA 8; Figs. 4A \& 11; Tennevassås, 2018). A vague coarsening-upwards trend accompanied by decreasing gamma-ray values, increasing velocities, and a change to light grey-coloured shales are observed (Fig. 11). The amount of interbedded, very fine-grained, lenticular, wave-ripple cross-laminated sandstones also increases upwards, marking a gradual transition into FA 11 (Figs. 4 \& 11). Pyrite and siderite nodules are also present. Bioturbation is sparse (BI $0-1$ ), but tends to increase upwards (BI 1-3). The ichnodiversity is low and limited to Arenicolites, Palaeophycus, Gyrophyllites and Schaubcylindrichnus freyi in the sandstones.

\section{Interpretation}

Based on its fine-grained, laminated nature, dark colour and TOC content, and low-diversity trace fossil assemblage, this facies association is interpreted to have been deposited in a restricted shelf setting below storm wave base. The presence of pyrite and siderite indicates reduced oxygen levels and variable salinity levels on the shallow shelf, possibly due to dilution of brackish water and stratification of the water column. The widespread occurrence of the shale unit suggests deposition during regional flooding of the Helvetiafjellet Formation coastal plain (Midtkandal et al., 2016). The association has been assigned an early Aptian age (Midtkandal et al., 2016; Grundvåg et al., 2017; This study), and a negative followed by a positive $\delta^{13} \mathrm{C}_{\text {org }}$ excursion demonstrated in well DH1 and in the Festningen outcrop section (Fig. 5; Midtkandal et al., 2016; Vickers et al., 2016) suggests a regional event that may correlate globally with the early Aptian Oceanic Anoxic Event 1a (OAE1a). The coarsening-upward trend and the presence of waveripple cross-laminated sandstones indicate shallowing of the shelf and marks the arrival of the Dalkjegla Member inner shelf to shoreface sandstone sheet (FA 11). The trace fossil assemblage is attributable to the distal Cruziana Ichnofacies (e.g., MacEachern et al., 2007).

\section{Source-rock characteristics}

The TOC and Rock-Eval data from the shale unit in the lower part of the Carolinefjellet Formation (FA 10) are given in Table 2, and selected parameters are shown in Fig. 13. The results of the GC-MS analysis are shown as a total ion chromatogram in Fig. 14. Within the short sample interval $(<10 \mathrm{~m}$; Fig. 11) and with the limited number of samples analysed (14 in total; Table $2)$, no particular vertical TOC trends are observed in the investigated shale unit. The TOC content in the 14 samples ranges between 1.27 and 2.10 wt.\% with an average of $1.79 \mathrm{wt} . \%$, and $\mathrm{T}_{\max }$ values are in the range of $438-455^{\circ} \mathrm{C}$ with an average of $446^{\circ} \mathrm{C}$. In general, the samples have low $\mathrm{HI}$ values ranging from 31 to $214 \mathrm{mg}$ $\mathrm{HC} / \mathrm{g}$ TOC with an average of c. $122 \mathrm{mg} \mathrm{HC} / \mathrm{g}$ TOC. The Rock-Eval $\mathrm{S}_{1}$ values fall in the range $0.25-0.85 \mathrm{mg}$ $\mathrm{HC} / \mathrm{g}$ rock with an average of $0.46 \mathrm{mg} \mathrm{HC} / \mathrm{g}$ rock, and the $\mathrm{S}_{2}$ values range from 0.57 to $3.94 \mathrm{mg} \mathrm{HC/g}$ rock with an average of $2.14 \mathrm{mg} \mathrm{HC} / \mathrm{g}$ rock (Table 2). However, considering the two wells individually, some of the average values are slightly higher in well DH5R $(\mathrm{TOC}=$ 1.74 wt. $\% ; \mathrm{T}_{\max }=450^{\circ} \mathrm{C} ; \mathrm{S}_{1}=0.58 ; \mathrm{S}_{2}=3.10 ; \mathrm{HI}=180$ mg HC/g TOC) than well DH1 (TOC $=1.82 \mathrm{wt} . \% ; \mathrm{T}_{\max }$ $=444^{\circ} \mathrm{C} ; \mathrm{S}_{1}=0.40 ; \mathrm{S}_{2}=1.60 ; \mathrm{HI}=90 \mathrm{mg} \mathrm{HC} / \mathrm{g} \mathrm{TOC}$ ) (Table 2; Fig. 13). The GC-MS analysis shows a smooth distribution of $n$-alkanes extending beyond $n-\mathrm{C}_{35}$ with a relatively high concentration of long-chained $n$-alkanes (Fig. 14). There is, however, a prominent lack of frontend $n$-alkanes $\left(<n-\mathrm{C}_{15}\right)$. The measured pristane $/ n-\mathrm{C}_{17}$ and the phytane $/ n-\mathrm{C}_{18}$ ratios are around 0.76 and 0.33 , respectively, with a relatively high $\mathrm{Pr} / \mathrm{Ph}$ ratio of 2.32 (Fig. 14).

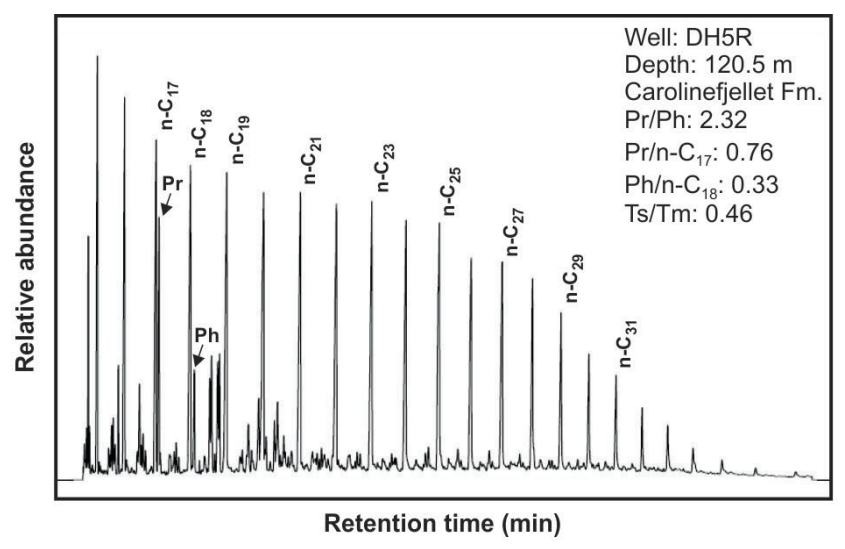

Figure 14. Gas chromatogram of the extracted sample from DH5R. Note the relatively high concentrations of long-chained n-alkanes and the high $\mathrm{Pr} / \mathrm{Ph}$ ratio ( $>2)$. The latter suggests that the source rock formed in a marine setting strongly influenced by terrigenous organic matter.

\section{Dinocyst biostratigraphy}

Dinocysts are rather rare and poorly preserved in the analysed samples, and the organic matter is generally dominated by saccate pollen and wood fragments. The dinocyst biostratigraphy of the Helvetiafjellet and Carolinefjellet formations is referred to the zonation of NE Greenland established by Nøhr-Hansen (1993). Only 
the most important Lower Cretaceous dinocyst markers recognised in the studied material are discussed here (Fig. 15).

\section{Age of the Rurikfjellet Formation}

Numerous samples, especially in the basal part of the formation, are barren of dinocysts. The most common dinocyst species within the Rurikfjellet Formation is Oligosphaeridium complex, whereas the stratigraphically most important dinocysts include: Endoscrinium hauterivianum, Oligosphaeridium abaculum, less abundant Nelchinopsis kostromiensis and Stanfordella fastigiata (Fig. 15). The stratigraphic range of $E$. hauterivianum is restricted to the Hauterivian, with its last occurrence in the lowermost upper Hauterivian (Duxbury, 2001). O. abaculum is regarded as an upper Hauterivian to lowermost Barremian marker (Costa \& Davey, 1992), and N. kostromiensis was previously recorded from the upper Hauterivian to lower Barremian in NE Greenland (Nøhr-Hansen, 1993), from the upper Valanginian to lower Barremian in the North Sea (Duxbury, 2001), and from the Hauterivian to lower Barremian in the Barents Sea (Århus et al., 1990). S. fastigiata ranges from lower Hauterivian to lowermost upper Barremian (Bailey, 2017). Thus, the co-occurrence of E. hauterivianum, $N$. kostromiensis and $O$. abaculum suggests an early late Hauterivian age for the upper part of the Rurikfjellet Formation (232-288 m in well DH5R; Fig. 4). The occurrence of $O$. abaculum and N. kostromiensis indicates a latest Valanginian to early Hauterivian age for the lower part of the formation. Our results confirm the previous age assessment of Århus (1992), and constrains the age of the Adventpynten member to the earliest late Hauterivian (Fig. 4).

Samples from the Bohemanflya outcrop section and the uppermost sample from the DH5R well yield few specimens of questionable Pseudoceratium anaphrissum (Fig. 15K, P). These specimens differ from the holotype by their densely distributed spines and more rounded outline (cf., Sarjeant, 1966). In addition, the uppermost samples from the Bohemanflya outcrop section yield common to abundant specimens previously recorded as Nyktericysta? pannosa by Grøsfjeld (1992) (Fig. 15M$\mathrm{O})$. These specimens of $N$.? pannos $a$ differ slightly from the holotype by their less pronounced lateral horns (cf., Duxbury, 1980). However, the presence of questionable $P$. anaphrissum and N? pannosa indicate a Hauterivian to early Barremian age for the uppermost few metres of the Rurikfjellet Formation at Bohemanflya, confirming the age suggestion by Grøsfjeld (1992).

\section{Age of the Helvetiafjellet Formation}

Samples of the Helvetiafjellet Formation (Fig. 15) yield dinocysts with relatively long age ranges, e.g.,
O. complex (first occurrence in the lower Valanginian; Duxbury, 2001) and Sirmiodinium grossii (last occurrence in the lower Aptian; Costa \& Davey, 1992; Nøhr-Hansen, 1993). Sporadic occurrences of Subtilisphaera perlucida, $P$. anaphrissum and Odontochitina nuda are recorded within the Helvetiafjellet Formation (Fig. 15). In NE Greenland, $O$. nuda is observed in the Barremian to lower Aptian, $S$. perlucida is recorded in the lower Barremian to middle Albian (Nøhr-Hansen, 1993), and P. anaphrissum is restricted to a short time range in the lower Barremian (Costa \& Davey, 1992; Bailey 2017). The dinocyst assemblage is similar to the Pseudoceratium anaphrissum Subzone (I.2 of Nøhr-Hansen, 1993), suggesting that the lower half of the formation is of early Barremian age as previously suggested by Grøsfjeld (1992). The upper half of the Helvetiafjellet Formation yields $O$. nuda which is characteristic of the lower Aptian in NE Greenland (Nøhr-Hansen, 1993). Based on these age determinations, the uppermost part of the Helvetiafjellet Formation is referred to the early Aptian. This is in agreement with an absolute $\mathrm{Ar} / \mathrm{Ar}$ age of 123.3 $\pm 0.2 \mathrm{Ma}$ obtained from zircons in a bentonite layer in the middle of the formation in the DH3 well (Corfu et al., 2013; Midtkandal et al., 2016).

\section{Age of the Carolinefjellet Formation}

Two samples were studied from the base of the Carolinefjellet Formation. The samples yield amongst others $O$. nuda, Pseudoceratium cf. retusum, S. perlucida and Muderongia pariata (Fig. 15). In NE Greenland, $M$. pariata and $P$. cf. retusum are present in lower Aptian strata (Nøhr-Hansen, 1993). Thus, this assemblage can be referred to the earliest Aptian (Pseudoceratium nudum Zone II of Nøhr-Hansen, 1993). A similar age for the basal part of the Carolinefjellet Formation has also recently been suggested by Midtkandal et al. (2016) and Vickers et al. (2016). Previous ammonite studies by Nagy (1970) assigned an Aptian age for the Dalkjegla Member and late Aptian to early Albian age for the transitionally overlying Innkjegla Member.

\section{Subsurface and outcrop correlations}

The well correlation confirms the threefold lithostratigraphic subdivision typical of the Lower Cretaceous succession elsewhere in Svalbard (Fig. 4; Parker, 1967; Midtkandal et al., 2008). The seven wells are lithostratigraphically correlated by using two datum surfaces (Fig. 4). Datum 1 is the top of the Festningen Member, and Datum 2 is the flooding surface on top of the Helvetiafjellet Formation (FA 10; Table 1). Datum 1 is marked by an abrupt transition from cross-bedded sandstones (FA 5) into a generally $<1$ m-thick coaly 


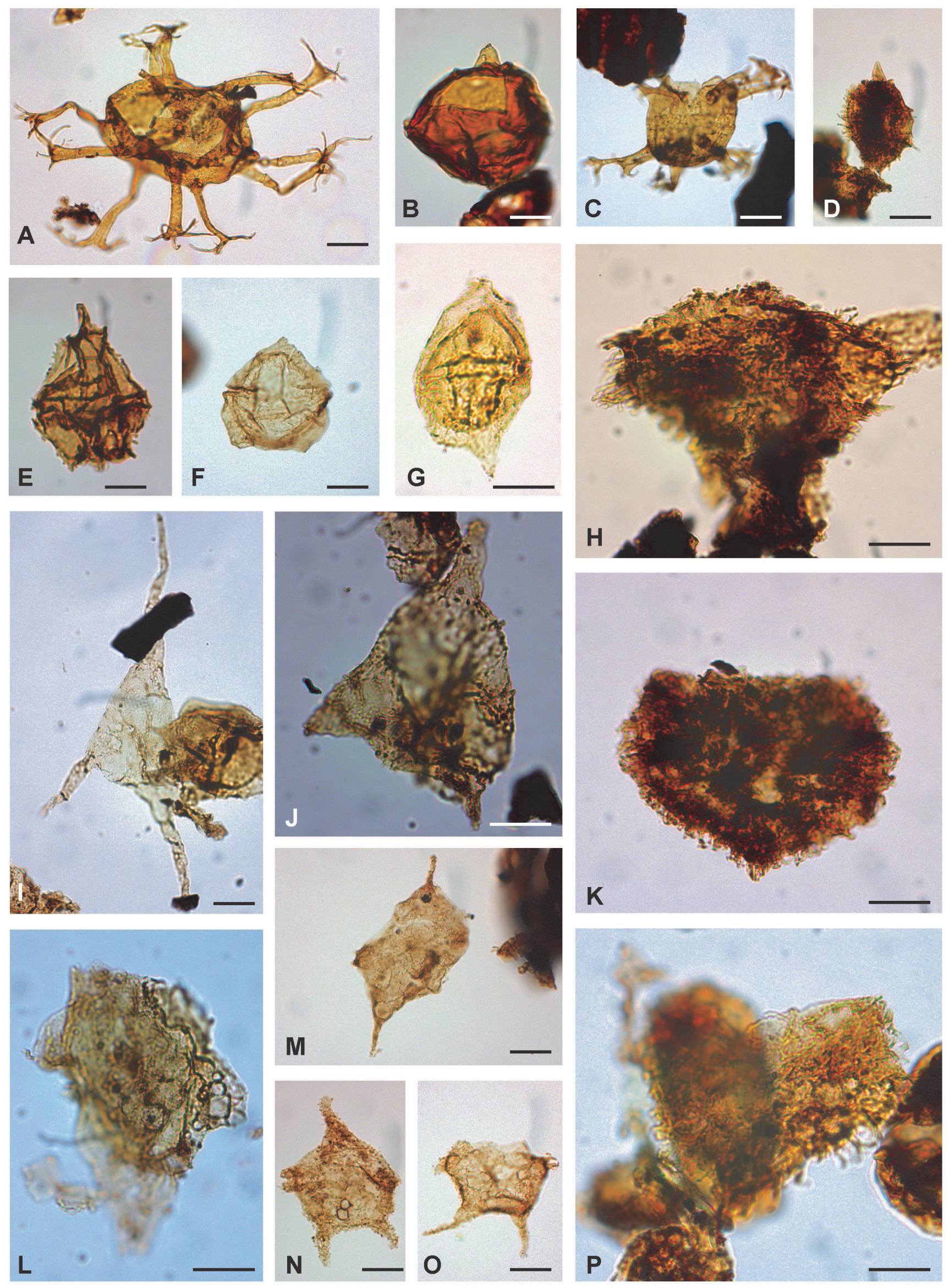


Figure 15. The most important Lower Cretaceous dinocyst markers identified in this study. The scale bars correspond to $20 \mu \mathrm{m}$. (A) Oligosphaeridium complex, DH5R, depth $180 \mathrm{~m}$, slide nr. 26191-8. (B) Endoscrinium hauterivianum, Bohemanflya, level 19.25 m, slide nr. 26292-7. (C) Oligosphaeridium abaculum, DH5R, depth $194 \mathrm{~m}$, slide $n r$. 26192-7. (D) Nelchinopsis kostromiensis, Bohemanflya, level $54.29 \mathrm{~m}$, slide $n r$. 26291-7. (E) Stanfordella fastigiata, DH5R, depth 380 m, slide nr. 26198-7. (F) Sirmiodinium grossii, DH1, depth 258.9 m, slide $n r$. 26285-7. (G) Subtilisphaera perlucida, DH2, depth $186.55 \mathrm{~m}$, slide $n r$. 26513-09. (H) Pseudoceratium anaphrissum, DH2, depth $149.5 \mathrm{~m}$, slide $n$ r. 2651111. (I) Odontochitina nuda, DH2, depth $141.88 \mathrm{~m}$, slide $n r .26510$ 09. (J) Pseudoceratium cf. retusum, DH2, depth $138.18 \mathrm{~m}$, slide $n \mathrm{r}$. 26509-10. (K) questionable Pseudoceratium anaphrissum, DH5R, depth $180 \mathrm{~m}$, slide $n \mathrm{r}$. 26191-8. (L) Muderongia pariata, DH2, depth $138.18 \mathrm{~m}$, slide $n$ r. 26509-10. (M-O) questionable Nyktericysta? pannosa, Bohemanflya, level $82.58 \mathrm{~m}$, slide $n r$. 26290-8. $(P)$ questionable Pseudoceratium anaphrissum, Bohemanflya, level $87.63 \mathrm{~m}$, slide $n$ r. 26289-8.

shale unit. In some outcrops, particularly in eastern Spitsbergen, the shale thickens by several metres and delta-front deposits (FA 8) are observed to downlap onto the Datum 1 surface (e.g., Nemec et al., 1988; Steel et al., 2000; Midtkandal et al., 2007; Onderdonk \& Midtkandal, 2010). In the Festningen outcrop section (Figs. 1C \& 5), the coaly shale separates two fluvial sandstone bodies, where the lower one accumulated in a braidplain setting and the upper one in a distributary channel in a lower delta-plain setting (Fig. 5; Steel et al., 1978). Thus, the coaly shale layer may represent a good candidate for constituting the proximal part of a marine flooding surface. Datum 2 separates paralic deposits of the Helvetiafjellet Formation from open-marine shelf deposits of the overlying Carolinefjellet Formation (Fig. 11). The surface is overlain by an up to $10 \mathrm{~m}$-thick early Aptian shale unit (FA 10; Table 1; Figs. 4, 5, 6 \& 11) which accumulated during a regional flooding event (Fig. 6; Midtkandal et al., 2016; Grundvåg et al., 2017). At the Festningen and Forkastningsfjellet outcrop sections, mouth-bar units (FA 8) >10 m thick characterise the uppermost part of the Helvetiafjellet Formation (Figs. 5, $6 \&$ 11). In these locations, the marine shale unit rests conformably on top of the mouth-bar units. In the wells, the laterally equivalent delta-front deposits are thinner $(<5 \mathrm{~m}$ thick), heavily wave-reworked, and truncated by a matrix-supported conglomerate containing extrabasinal lithic clasts and intraformational siderite clasts (Fig. 11). This suggests that wave winnowing and ravinement took place prior to deposition of the marine shale unit. Thickness variations at the order of some few tens of metres occur within the Helvetiafjellet Formation (Figs. 4-6). This does not only imply that the amount of erosion associated with the transgressive ravinement varied significantly across the study area, but also testifies to the erosive base of the unit (e.g., Midtkandal \& Nystuen, 2009) and the overall lobate character of the deltas which deposited the Helvetiafjellet Formation (e.g., Steel et al., 2000).

Another prominent surface of regional extent is the subaerial unconformity which separates the Helvetiafjellet Formation from the underlying Rurikfjellet Formation (Figs. 4-6). The unconformity is of early Barremian age (e.g., Grøsfjeld, 1992; This study), and is recognised by an abrupt facies transition from open-marine shelf and delta-front/shoreface deposits in the Rurikfjellet Formation (FAs 1 and 2) below to fluvial braidplain (FA 5) deposits of the Festningen Member (Fig. 4) above the unconformity. In the subsurface, a prominent drop in gamma-ray values defines the unconformity (Figs. 4-6). For correlation purposes, the highly undulating character of the unconformity (Fig. 4; Gjelberg \& Steel, 1995; Midtkandal et al., 2007, 2008) makes it less suitable as a datum for correlation if realistic depositional architectures are to be obtained.

The Wimanfjellet Member in the lower part of the Rurikfjellet Formation consists of shales and mudstones (FA 1; Table 1), whereas the Kikutodden Member in the upper part of the formation is more heterolithic and sandstone-rich (FA 2; Table 1; Fig. 4). Formally, the base of the Kikutodden Member is defined by the first occurring sandstones above the shales of the Wimanfjellet Member (Midtkandal et al., 2008). In the wells, however, a high gamma-ray peak (e.g., 242 $\mathrm{m}$ in well DH4; Fig. 4) immediately followed by a prominent decrease and a coarsening-upwards trend occur approximately $20 \mathrm{~m}$ below the first occurring sandstone. In the cores, the coarsening-upwards trend seen in the gamma-ray logs is consistent with an increase in the amount of thin-bedded lenticular sandstones and more silty to sandy shales (e.g., 242$227 \mathrm{~m}$ in well DH4; Fig. 4). Collectively, this suggests that the regression represented by the Kikutodden Member was initiated earlier than what is captured by the lithostratigraphic correlation. The uppermost heterolithic, thin-bedded, hummocky cross-stratified sandstone units of the Kikutodden Member are in many outcrops capped by a 2-30 m-thick marine shale package (Figs. 4-6). The thickness variation of this shale package probably reflects the erosive character of the overlying Helvetiafjellet Formation, and its presence points to a semi-regional flooding event prior to uplift and formation of the Barremian subaerial unconformity.

In the subsurface, the most prominent deviation from the typical stratigraphic expression of the Rurikfjellet Formation is recorded in wells DH1 and DH2, where the 150 m-thick succession of mass-flow (FA 4) and prodelta slope (FA 3) deposits of the Adventpynten member occur (Figs. 2, 4 \& 12). No similar deposits have been observed in outcrop elsewhere within the study area. 


\section{Discussion}

The ensuing discussion primarily focuses on the palaeogeographic development of the LCS in central Spitsbergen based on facies distributions, palaeocurrent flow directions, as well as the subsurface and outcrop correlations (Figs. 4-6). The timing of events is based on the biostratigraphic framework established in this study (Figs. $2 \& 15$ ).

\section{Palaeogeographic development of the Rurikfjellet Formation}

The lower shale-dominated (FA 1) Wimanfjellet Member (Fig. 2; Dypvik et al., 1991a; This study) represents the most distal part of the depositional system during Valanginian-early Hauterivian times and formed on an open-marine shelf well below storm wave base (Fig. 16A). The unit exhibits a slight upwards increase in the amount of siltstone and the degree of bioturbation, indicating shoaling from outer- to innershelf environments as nearby shorelines successively approached the study area from the west or northwest (Fig. 16B; Dypvik et al., 1991b). This interpretation is consistent with previous studies based on microfossils (Løfalidi \& Thusu, 1976) and geochemistry (Dypvik, 1985; Hvoslef et al., 1986). Due to its shale-dominated character, extensive regional distribution (present in all investigated sections and wells; Fig. 6) and laterally continuous thickness (c. $200 \mathrm{~m}$ in average), the offshore deposits of the Wimanfjellet Member constitute an important part of the top seal for the underlying Triassic to Middle Jurassic $\mathrm{CO}_{2}$ reservoir unit (Braathen et al., 2012).

The transitionally overlying Hauterivian to lowermost Barremian Kikutodden Member comprises vertically stacked coarsening-upwards parasequences (Figs. 4-6). The parasequences consist of offshore transition to lower shoreface deposits (FA 2). The lack of shallower facies suggests either that such deposits were eroded during intervening transgressions (due to wave ravinement) or that they never developed due to rapid progradation into shallow water; or due to the low-gradient ramp setting of the basin (e.g., Midtkandal \& Nystuen, 2009) giving rise to widely distributed facies belts. No transgressive lags typical of transgressive wave ravinement or evidence of forced regression (e.g., bypass surfaces, sharpbased shoreface deposits or foreshortened stratigraphy) have been identified in the parasequences. Thus, it seems more likely that the parasequences developed as a fully subaqueous system (within the study area) on a low gradient ramp. Although upper shoreface and shallower facies are not present in the Kikutodden Member in the study area, such deposits do occur within the member in southernmost Spitsbergen (Grundvåg \& Olaussen, 2017). Although these southern deposits lithostratigraphically belong to the Kikutodden Member, they probably represent a clastic wedge that developed separately from the parasequences documented in this study (Grundvåg et al., 2017).

The lowermost parasequences of the Kikutodden Member represent successive basinward progradation of distal shoreline tongues (Fig. 16B-D). The uppermost parasequences contain less sandstone and exhibit retrogradational stacking with units becoming successively thinner upwards (Figs. 4 \& 6). This indicates that the Kikutodden Member shoreline system retreated (Fig. 16E) prior to the formation of the subaerial unconformity at the base of the overlying Helvetiafjellet Formation (Fig. 16F). The open-marine shale package, which in many outcrops (locally eroded) separates the upper parasequences in the Kikutodden Member from the overlying Helvetiafjellet Formation, may thus represent a latest Hauterivian to earliest Barremian semi-regional marine flooding. Collectively, the Rurikfjellet Formation forms a large-scale, secondor third-order, regressive-transgressive sequence (Fig. 16A-E) which developed in the Valanginian to earliest Barremian as an early sedimentary response to ongoing uplift north and west of Svalbard and igneous activity related to the HALIP in the east-northeast.

\section{The origin of mass-flow deposits in the Rurikfjellet Formation}

The most remarkable observation from this study is the $130 \mathrm{~m}$-thick succession of mass-flow deposits of the Adventpynten member in the lower part of the Rurikfjellet Formation in wells DH1 and DH2 (FA 4; Figs. 2, 4A \& 12; Mork-Jansson et al., 2010; Braathen et al., 2012). The mass-flow deposits are dated to be of an earliest late Hauterivian age, where the equivalent stratigraphic interval in the other wells is characterised by Valanginian to earliest Hauterivian shales of the Wimanfjellet Member (Fig. 4A). Thus, the age of the Adventpynten member corresponds directly to the hummocky cross-stratified sandstone-rich parasequences of the Kikutodden Member in the other wells (Fig. 4). It is noteworthy, however, that these sandstone units occur stratigraphically above the mass-flow deposits of the Adventpynten member and laterally correlate to prodelta slope deposits in wells DH1 and DH2 (FA 3; Fig. 4A). The origin of the mass-flow deposits is thus enigmatic in the sense that the Rurikfjellet Formation is traditionally interpreted to have been accumulated on a flat to gently sloping shelf (Dypvik et al., 1991b; Midtkandal \& Nystuen, 2009).

Mass-flow deposits with a remarkably similar character have been described as syn-sedimentary infill deposits of collapse scars involving the Rurikfjellet and Helvetiafjellet formations in Kvalvågen, eastern Spitsbergen (Fig. 1; Nemec et al., 1988). The mass- 

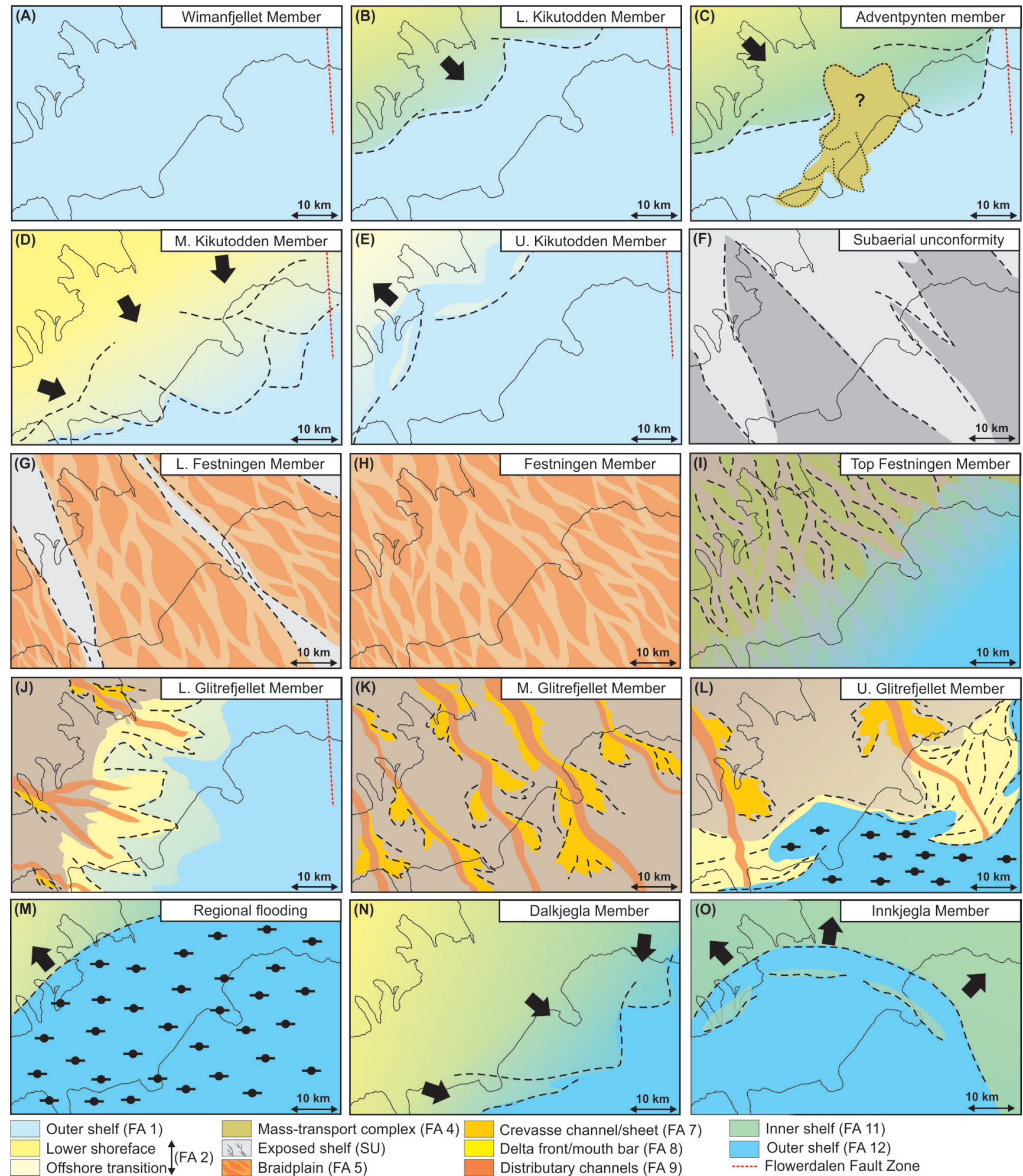

Lower shoreface 4 (FA 2) $\$ 1$ Exposed shelf (SU)

Prodelta/delta front (FA 3) $\square$ Flood plain (FA 6)

Figure 16. Palaeogeographic reconstruction for the study area. The maps highlight the long-term evolution of the depositional environments and distribution of facies associations in the Rurikfjellet $(A-E)$, Helvetiafjellet $(F-L)$ and Carolinefjellet $(M-O)$ formations. The timing of the events is based on the sequence-stratigraphic and biostratigraphic framework established in this study. L-lower, $M-$ middle, and $U-u p p e r$ denotes specific stratigraphic intervals for which the palaeogeographic maps intend to illustrate. See main text for details.

flow deposits were derived from nearby slopes by retrogressive slumping of the slump scar margins, and by later delta-front progradation into and eventually across the collapse scar.
We suggest two alternative interpretations for the origin of the Adventpynten member. The first interpretation is that it represents a base-of-slope mass transport complex that accumulated in front of the advancing delta system of the Kikutodden Member. Its localised distribution 
and the occurrence of a slump block of delta-plain origin within the mass-flow deposits (in well DH2; Figs. 4, 9 \& 12) indicate sourcing from an unstable delta front of early late Hauterivian age, thus predating the Barremian Helvetiafjellet Formation fluvio-deltaic system. Prodelta slope to delta-front deposits (FA 3) conformably overlying the mass-flow deposits (FA 4) suggest that this delta front prograded in concert with and later across its associated base-of-slope mass transport complex. Recently, it has been suggested that the Lower Cretaceous succession in Svalbard may represent the proximal part of a prograding shelfprism-type clinoform system (Grundvåg et al., 2017). Such clinoform successions are reported widely on the Barents Shelf (Marin et al., 2016). Although clinoform geometries at these scales are yet to be demonstrated in Svalbard due to outcrop limitations, their presence cannot be ruled out with certainty.

The second interpretation is that the Adventpynten member represents a mass transport complex similar to the slump-scar deposits described from Kvalvågen in eastern Spitsbergen (Nemec et al., 1988; Onderdonk \& Midtkandal, 2010). Seismic activity along the N-Strending Lomfjorden Fault Zone has generally been invoked as the main triggering mechanism for these collapse scars (Nemec et al., 1988; Onderdonk \& Midtkandal, 2010). It is noteworthy that wells DH1 and $\mathrm{DH} 2$ are located c. $20 \mathrm{~km}$ west of the long-lived Billefjorden Fault Zone. Although it has been disputed whether this lineament was active during the Mesozoic, similar-trending Late Palaeozoic lineaments on the shelf immediately east of Svalbard were reactivated both in the Late Jurassic and in the Hauterivian to early Barremian (Kairanov et al., 2018). Thus, it cannot be excluded that short-lived tectonic pulses led to small, localised collapses in the studied succession. A diamictite representing a debris-flow deposit also occurs in the Upper Jurassic Agardhfjellet Formation in well DH5R (Koevoets et al., 2019). This may support the notion of proximity to an active fault scarp that periodically provided a local source for sediments and enabled sufficient relief to initiate gravity flows.

\section{Palaeogeographic development of the Helvetiafjellet Formation}

The unconformity at the base of the Helvetiafjellet Formation (Fig. 16F) is of early Barremian age (Grøsfjeld, 1992; This study). A similar age is also inferred for the uppermost part of the Rurikfjellet Formation, suggesting that the unconformity represents a hiatus of $<2$ myr (Grøsfjeld, 1992; This study). The Festningen Member was deposited in the early Barremian during relative sea-level rise immediately following the uplift which created the subaerial unconformity (Fig. 16F-H; e.g., Midtkandal et al., 2007).
Based on the lateral thickness variations of the Festningen Member and the variable degree of preservation of the underlying shale package in the uppermost Rurikfjellet Formation, it is suggested that the Festningen Member was deposited in wide, and partially coalescing, low-relief river valleys (Fig. 16G). The palaeo-topography is demonstrated from the well correlation (Fig. 4A), where the braidplain deposits of the Festningen Member display a thickness decrease in well DH5R. These braidplain deposits were also deposited within a river valley, but were probably situated on the valley margin or a topographic saddle between two valleys. Similar observations were made in Louisdalen (Fig. 1C) where the braidplain deposits of the Festningen Member thin from more than $8 \mathrm{~m}$ to 0.5 $\mathrm{m}$ thickness over a distance of c. $300 \mathrm{~m}$. Upon filling the valleys, the fluvial system developed into an extensive braidplain depositing a fluvial sandstone sheet across the study area (Fig. 16H). The lateral extent of the fluvial sandstone sheet is attributed to the rapid southeastward shoreline progradation in the early Barremian due to uplift of the northern shelf. This resulted in extension of the shelf equilibrium profile, reduction of the shelf gradient, and thereby limited vertical accommodation space in the continental areas immediately following the regressive-transgressive turn-around. The limited accommodation space promoted frequent channel avulsion and cannibalism resulting in the channels building laterally instead of aggrading vertically (Midtkandal \& Nystuen, 2009). Ultimately, this resulted in the development of an extensive fluvial sandstone sheet (Fig. 16H).

The transgressive coaly shale unit which caps the Festningen Member most likely formed due to a rising groundwater table during an early stage of the flooding (Fig. 16I; Nemec, 1992; Midtkandal et al., 2007). Delta-front deposits (FA 8) downlapping onto the top of the Festningen Member at several localities (e.g., Bohemanflya; Figs. 1C \& 6), indicate that at one stage, the relative sea-level rise must have exceeded the rate of fluvial sediment supply and resulted in a regional flooding of the fluvial braidplain (Fig. 16I). When the rate of relative sea-level rise eventually outpaced the rate of sediment supply, enough accommodation was created for a deltaic system to subsequently develop and prograde across the shallow shelf which had formed by drowning of the braidplain (Fig. 16J).

At the Festningen locality, the Festningen Member originally includes two sandstone channel bodies (Fig. 6, level 180-200 m; Steel et al., 1978). The two channel bodies are fundamentally different in their architectures. The lower one has been interpreted to be a braidplain deposit, and the upper one to be a meandering channel deposit showing strong indications of lateral migration and point-bar development (Steel et al., 1978). A thin (few metres thick) shale deposited in an interdistributary bay environment separates the two 
channel bodies (Fig. 6). Thus, it is suggested here that only the lowermost channel body formally belongs to the braidplain deposits of the Festningen Member (Fig. 6 ), and that the interdistributary bay unit above formed during the suggested marine flooding of the braidplain. The upper channel body may represent a distributary channel feeding the delta-front deposits (FA 8) which locally occur on top of the Festningen Member (e.g., at Bohemanflya or in Kvalvågen; Figs. 1C \& 6; Nemec et al., 1988). The change from an incised valley and braidplain setting to an unconfined lower delta plain setting may explain the architectural differences between the two channel bodies.

No obvious stacking trends are observed in the Glitrefjellet Member, indicating that the coastal plain was aggrading and that autogenic processes had a major influence on the facies development (e.g., Midtkandal et al., 2007). However, accommodation was continuously being created through subsidence and relative sealevel rise, resulting in marine incursions occurring more frequently as is evident from the presence of marine trace fossils. The mouth-bar unit (FA 8) which occurs in the uppermost Glitrefjellet Member at the Forkastningsfjellet and Festningen outcrop sections (Fig. 1C) reflects the overall transgressive development and retrogradational retreat of the Helvetiafjellet Formation shoreline (Figs. $6 \& 16 \mathrm{~L}$ ). Due to localised transgressive ravinement associated with the final drowning of the Helvetiafjellet Formation shoreline, the mouth-bar unit is thinner and more wave-reworked in the wells (Fig. 4A). Notice also that Nemec (1992) documented barrier bar deposits in the uppermost part of the formation, both in Kvalvågen east of the study area and in Hiorthamn some few km north of Longyearbyen (Fig. 1C).

\section{Palaeogeographic development of the Carolinefjellet Formation}

The transgressive retreat of the Helvetiafjellet Formation shoreline culminated in a marine flooding in the early Aptian, depositing the regionally extensive sapropelic shale unit which marks the boundary between the Helvetiafjellet and Carolinefjellet formations (FA 10). The Helvetiafjellet Formation coastal plain drowned and the flooding thus created a shallow, gently-sloping shelf (Fig. 16M). The lower sandstone-dominated part of the Dalkjegla Member exhibits a shoaling-upward facies trend recording renewed progradation of the shoreline onto the shelf (Figs. $11 \& 16 \mathrm{~N}$ ). The Dalkjegla Member is characterised by interbedded shales and sandstones with wave- and storm wave-generated structures suggesting deposition in an offshore transition to lower shoreface setting (FAs 11-12; Table 1). Coarse-grained sandstones of upper shoreface origin occur in the west and northwest, suggesting the presence of a shoreline in those directions beyond the present-day outcrop belt. The sheet-like architecture of the unit directly relates to the low-angle, distally-deepening (from the northwest to the southeast) ramp setting. The relatively shallow-water depths and the high energy of depositional processes inhibited accumulation of fine sand and mud on the inner shelf. Reworking by storm waves, potentially in combination with tidal currents (e.g., Birkenmajer, 1966), thus resulted in a net basinward transport of the sediments and shaped nearshore sands into amalgamated, laterally persistent sandstone sheets.

Similar to the Rurikfjellet Formation, no foreshore, backshore or paralic deposits have been recorded at any locality in the Carolinefjellet Formation in Svalbard (Grundvåg et al., 2017). This points to predominantly subaqueous deposition or low-angle and extensive facies belts with the shoreline itself located somewhere in the west to northwest beyond the present-day outcrop belt (Fig. 16N).

The upper part of the Dalkjegla Member transitionally grades into the overlying mudstone-dominated Innkjegla Member (FA 12; Fig. 4). This facies trend is recorded in the wells and investigated outcrops, indicating a longterm, regional-scale retreat of the shoreline and a return to outer-shelf environments across the entire study area (Fig. 16O). This demonstrates that the Dalkjegla Member represents a second- or third-order regressivetransgressive sequence (Fig. 16M-O) similar to the trend of the Rurikfjellet Formation.

\section{Source-rock potential of the lower Aptian shale}

The TOC analyses of the samples of the shale unit in the lowermost part of the Carolinefjellet Formation (Fig. 11) all show values greater than $1 \mathrm{wt} . \%$, indicating a fair to good source rock (Fig. 13A, B; Table 2). However, most of the samples have relatively low HI values, particularly the well DH1 samples (generally <200; Table 2). Vitrinite reflectance analyses of coal seams in the Paleocene Firkanten Formation yield $\mathrm{R}_{\mathrm{o}} \%$ values up to 0.7 (Marshall et al., 2015), and coals from the Helvetiafjellet Formation in central Spitsbergen yield $\mathrm{R}_{\mathrm{o}} \%$ values up to 1.1 (Nøttvedt et al., 1993). The average $\mathrm{T}_{\text {max }}$ value of $446^{\circ} \mathrm{C}$, in combination with the published vitrinite reflectance data, suggests peak oil window maturities (Fig. 13C). The organic facies in the sourcerock unit appear to be mostly of Type III (gas-prone) kerogen for the well DH1 samples and mixed Type II-III (oil- and gas-prone) kerogen for the DH5R samples (Fig. 13B-D). The HI and OI values plotted in a modified van Krevelen diagram (Fig. 13D) also confirm a mostly gas-prone source rock in well DH1. However, the well DH5R samples in general have higher $\mathrm{S}_{2}$ and $\mathrm{HI}$ values than the well DH1 samples (Fig. 13B, C; Table 2), possibly indicating that the source-rock unit represents an increased oil potential eastwards in the basin. The two well sites are located c. $7 \mathrm{~km}$ apart, with well DH1 representing a more proximal position relative to the 
palaeoshoreline (to the NW) and the West Spitsbergen Fold-and-Thrust Belt compared to well DH5R (Fig. 1). Thus, the observed differences may reflect lateral variations in primary depositional conditions (e.g., proximity to a fluvial point source) or regional thermal maturity trends. Alternatively (but less likely), the differences may reflect the various analytical approaches used by the two labs analysing the samples.

Based on the Rock-Eval and GC-MS analyses, as well as the kerogen type, a wet gas condensate-prone source rock is suggested for the unit. The analysed extracted samples show a lack of front-end $n$-alkanes $\left(<n-\mathrm{C}_{15}\right)$, possibly reflecting evaporation of lighter components (or slight biodegradation) which may commonly result in the loss of $n$-alkanes at around $\mathrm{C}_{8}-\mathrm{C}_{15}$. A higher $\mathrm{Pr} /$ $\mathrm{Ph}$ ratio (2.32; Fig. 14) than most anoxic marine-derived oils $(\mathrm{Pr} / \mathrm{Ph}$ ratios $<1)$ is also evident, and the abundance of $n$-alkanes above $n-\mathrm{C}_{21}$ thus suggests a significant contribution from terrigenous organic matter. This indicates that the source-rock unit was not deposited in an anoxic marine setting, but rather in a suboxic environment (Fig. 13D) strongly influenced by input of terrestrial organic matter. Consequently, a more paralic marine setting for the shale unit is suggested. Rising sea level in shallow marginal seas typically result in increased organic production, salinity- or thermallyinduced water-column stratification, as well as nearshore trapping of terrestrial material, collectively leading to condensation and deposition of organic-rich sediments (Arthur \& Sageman, 2004). This is consistent with the interpretation that the investigated shale unit (FA 10; Table 1) was deposited during the early Aptian flooding of the Helvetiafjellet Formation coastal plain (e.g., Midtkandal et al., 2016). Although the present source rock is interpreted to be condensate- to gas-prone in the study area due to its proximal position, a potentially oilprone source rock may be present in distal positions on the shelf south of Svalbard where fully marine conditions prevailed during deposition. Barremian to Aptian oilprone source rocks are known to be locally present in, for example, the Fingerdjupet Subbasin (proven by well 7321/9-1S, see www.npd.no).

\section{Regional correlations and provenance perspectives}

Our study of the Lower Cretaceous succession in Nordenskiöld Land is consistent with previous regional palaeogeographic reconstructions indicating a northwestern provenance area, in particular for the Rurikfjellet and Helvetiafjellet formations (Fig. 16; Birkenmajer, 1984; Steel \& Worsley, 1984; Dypvik et al., 1991b, 2002; Gjelberg \& Steel, 1995; Midtkandal \& Nystuen, 2009). Across the study area, the Festningen Member is dominated by quartzose arenites and shows a consistent southeastward palaeocurrent direction (except in tidally influenced sections with bidirectional cross-strata; Fig. 8). Previous detrital zircon and petrographic studies indicate that the Helvetiafjellet Formation in general was sourced from a mixed metamorphic basement and sedimentary terrane to the west, with the interior of Northeast Greenland being the most obvious candidate (Røhr et al., 2007). A similar terrane also occurs in northern Svalbard, and apatite fission track studies demonstrate that northern Svalbard has been subjected to uplift and exposure since the Early Jurassic, particularly during Jurassic-Cretaceous times (Dörr et al., 2012). Thus, detrital inputs from northern Svalbard seem likely (e.g., Edwards, 1979). A northwestern provenance area has also been suggested for the underlying Bathonian to Ryazanian Agardhfjellet Formation (Dypvik et al., 1991, 2002; Koevoets et al., 2019). There is, however, a pronounced petrographic change from quartzose arenites in the Helvetiafjellet Formation to volcanic arenites in the overlying Carolinefjellet Formation (Edwards, 1979; Maher, 2001; Maher et al., 2004). In eastern Nordenskiöld Land (e.g., the Agardhbukta area; Fig. 1 ), this change is also observed in the upper part of the Helvetiafjellet Formation (Edwards, 1979; Birkenmajer, 1984). A $90^{\circ}$ switch in palaeocurrent directions from southeast- to northwest-directed is also evident in these areas (Birkenmajer, 1984). In addition, basaltic lava flows of Barremian-Aptian age are intercalated with the Helvetiafjellet Formation on Kong Karls Land (Worsely, 1986). Collectively, these findings point to influx of volcanic sediments attributed to erosion of the large igneous terrane (i.e., the HALIP) that formed east to northeast of Svalbard in the Barremain to Aptian (e.g., Maher et al., 2004; Corfu et al., 2013; Senger et al., 2014; Polteau et al., 2015). Although this source area became increasingly important from the early Aptian and onwards, it did not influence sediment routings in western Svalbard in pre-Aptian times (Edwards, 1979). In a circum-Arctic perspective, the Lower Cretaceous succession in Nordenskiöld Land bears similarities to age-equivalent strata at Kilen in the Wandel Sea Basin, NE Greenland (Fig. 3; Dypvik et al., 2002; Hovikoski et al., 2018), and partly to the Isachsen Formation of the Sverdrup Basin in the Canadian Arctic (Fig. 3; e.g., Tullius et al., 2014). In these successions, the sediments are very rich in quartz suggesting craton-interior and recycled orogenic provenances (Røhr et al., 2008, 2010). Provenance studies demonstrate that the interior parts of the Greenland Shield was the main source area for both successions (Røhr et al., 2008, 2010). Of particular interest is also the stratigraphic development reported from Kilen (Dypvik et al., 2002; Hovikoski et al., 2018), which during the Early Cretaceous was located south of Svalbard adjacent to the western margin of the Barents Shelf (Fig. 3). At Kilen, a Barremian-lower Aptian paralic unit (the Lichenryg Formation) truncates a Valanginian-Hauterivian offshore shale-dominated unit (the Dromledome Formation; Hovikoski et al., 2018), thus resembling the stratigraphic relationship observed between the Helvetiafjellet and Rurikfjellet formations 
of the Lower Cretaceous succession in Svalbard. The paralic unit at Kilen is further capped by a late Aptianmiddle Albian heterolithic unit (the Pil Member of the Galadriel Fjeld Formation) representing offshore to shoreface environments similar to the Carolinefjellet Formation in Svalbard. The stratigraphic similarities may thus indicate that the Lower Cretaceous successions in western Svalbard and Northeast Greenland were part of the same drainage system, at least during Valanginianearly Aptian times. Thus, it is concluded that western Svalbard, and probably the western rim of the Barents Shelf, had its main source in the west to northwest in Bathonian-early Aptian times. In Svalbard, a regional switch to a volcanic source area associated to the HALIP terrane to the northeast took place from the early Aptian and onwards, eventually becoming the dominant source area for most of the basins on the northern Barents Shelf (e.g., Kairanov et al., 2018).

\section{Conclusions}

The Lower Cretaceous succession in central Spitsbergen, Svalbard, consists of the Rurikfjellet, Helvetiafjellet and Carolinefjellet formations, and includes sediments deposited in environments ranging from fluvial to outer shelf. In this study, core- and outcrop-based sedimentological and biostratigraphic analyses have provided new insight into the depositional development of the Lower Cretaceous succession. The main conclusions are as follows:

- The Rurikfjellet Formation is of Valanginian to Hauterivian and earliest Barremian age, and consists predominantly of mudstone-dominated outer-shelf deposits (the Wimanfjellet Member) grading upwards into a sandstone-rich offshore transition to lower shoreface deposits in the upper part of the formation (the Kikutodden Member). The offshore transition to lower shoreface deposits stack into a series of shallowing-upwards parasequences which contain abundant hummocky cross-stratified sandstones. These units record successive shoreline progradations onto a storm-dominated shelf and reflect basinwide regression prior to the onset of shelf uplift and exposure in the Barremian.

- Base-of-slope mass-transport deposits (here informally referred to as the Adventpynten member) overlain by prodelta slope and delta-front deposits occur in wells DH1 and DH2, and record an earliest late Hauterivian regressive pulse which has previously not been recorded in Svalbard. The character of the mass-flow deposits, which include turbidites, debrites and slump deposits with rafted blocks of deltaplain origin, suggests that the flows originated from collapse of an unstable delta front.
- The Helvetiafjellet Formation is of early Barremian to early Aptian age and consists of fluvial braidplain, floodplain and interdistributary bay, crevasse splay, mouth-bar, and fluvial distributary channel deposits. The base of the formation is demarcated by a lower Barremian subaerial unconformity. Because the uppermost few metres of the Rurikfjellet Formation are also dated to be of early Barremian age, the subaerial unconformity records a hiatus of a limited time span $(<2$ myr $)$.

- The sandstones of the Festningen Member were deposited in a laterally and regionally extensive fluvial braidplain environment which persisted through the early Barremian. Lateral thickness variations occur within the unit, suggesting that erosional topography formed by fluvial incision existed locally.

- The upper part of the Helvetiafjellet Formation (the Glitrefjellet Member) shows an overall transgressive development. Aggradationally stacked fluvial overbank deposits are overlain by wavereworked mouth-bar deposits which are capped by a transgressive conglomerate containing extrabasinal lithic clasts and intraformational siderite clasts. Thus, an upwards increase of marine influence prior to the regional marine flooding of the Helvetiafjellet Formation coastal plain in the early Aptian is evident.

- A lower Aptian shale unit up to $10 \mathrm{~m}$ thick, which caps the transgressive conglomerate unit, marks the boundary between the Helvetiafjellet and Carolinefjellet formations. The shale accumulated during a regional flooding event which drowned the low-angle coastal plain of the Helvetiafjellet Formation and resulted in widespread (regional) deposition of organic-rich mud. Rock-Eval and GC-MS analyses indicate a fair to good source rock that may be capable of generating gas or condensate. The predominance of mixed Type II-III kerogen and the relative abundance of long-chained $n$-alkanes suggest a significant contribution from terrigenous organic matter, thus pointing to a suboxic paralic marine depositional environment.

- The lower half of the Dalkjegla Member is characterised by abundant hummocky cross-stratified sandstones and represents renewed storm-dominated shoreline progradation onto the shallow shelf of the drowned Helvetiafjellet Formation. The sandstones of the Dalkjegla Member gradually pass upwards into the shale-dominated Innkjegla Member, recording a long-term shoreline retreat.

- The investigated succession displays clear stratigraphic similarities to age-equivalent strata in NE Greenland, suggesting that these successions may have formed part of the same drainage system. 
Acknowledgements. This study forms part of the geological input to the Longyearbyen $\mathrm{CO}_{2}$ Lab project managed by the UNIS $\mathrm{CO}_{2}$ Lab AS (http://co2-ccs.unis.no), the SUCCESS center and the LoCrA (Lower Cretaceous Basin Studies in The Arctic) consortium managed by the University of Stavanger and The University Centre in Svalbard (UNIS). Parts of this study were conducted in association with the ARCEx project (Research Centre for Arctic Petroleum Exploration) which is funded by the Research Council of Norway (grant number 228,107). ENI, Norway is acknowledged for allowing us to publish RockEval data from well DH5R. KKŚ and HNH thank Charlotte Olsen, Annette Ryge and Dorthe Samuelsen for preparation of palynological microscope slides. Journal reviews by Edward Fleming and one anonymous reviewer are highly appreciated. This is a contribution of the NCCS (RCN\# 257579).

\section{References}

Arthur, M.A. \& Sageman, B.B. 2004: Sea-level control on sourcerock development: perspectives from the Holocene Black Sea, the mid-Cretaceous Western Interior Basin of North America, and the Late Devonian Appalachian Basin. In Harris, N.B. (ed.): The Deposition of Organic-Carbon-Rich Sediments: Models, Mechanisms, and Consequences, Society of Economic Paleontologists and Mineralogists Special Publication 82, pp. 35-59.

Bailey, D. 2017: Early Cretaceous zonation. Retrieved February 2017 from: http://www.biostrat.org.uk.

Bhattacharya, J.P. \& MacEachern, J.A: 2009: Hyperpycnal rivers and prodeltaic shelves in the Cretaceous Seaway of North America. Journal of Sedimentary Research 79, 184-209. https://doi.org/10.2110/jsr.2009.026.

Birkenmajer, K. 1966: Lower cretaceous tidal deposits of central vest Spitsbergen. Norsk Polarinstitutt Årbok 1964, 73-85.

Birkenmajer. K. 1984: Sedimentary features of the Helvetiafjellet Formation (Barremian) at Agardhbukta, East Spitsbergen. Studia Geologica Polonica 80, 59-70.

Bohloli, B., Skurtveit, E., Grande, L., Titlestad, G.O., Børresen, M.H., Jonhnsen, Ø. \& Braathen, A. 2014: Evaluation of reservoir and caprock integrity for the Longyearbyen $\mathrm{CO}_{2}$ storage pilot based on laboratory experiments and injection tests. Norwegian Journal of Geology 94, 171-187.

Bouma, A.H. 1962: Sedimentology of some flysch deposits: a graphic approach to facies interpretation. Elsevier, New York, 168 pp.

Braathen, A., Bælum, K., Christensen, H.H., Dahl, T., Eiken, O., Elvebakk, H., Hansen, F., Hanssen, T.H., Jochmann, M., Lie, T., Johansen, T.A., Johnsen, H., Larsen, L., Mertes, J. Mørk, A., Mørk, M.B., Nemec, W.J., Olaussen, S., Oye, V, Røed, K., Titlestad, G.O., Tveranger, J. \& Vagle, K. 2012: The Longyearbyen CO2 Lab of Svalbard, Norway - initial assessment of the geological conditions for $\mathrm{CO}_{2}$ sequestration. Norwegian Journal of Geology 92, 353-376.

Corfu F., Polteau S., Planke S., Faleide J.I., Svensen H., Zayoncheck, A. \& Stolbov, N. 2013: U-Pb geochronology of Cretaceous magmatism on Svalbard and Franz Josef Land, Barents Sea Large Igneous Province. Geological Magazine 150, 1127-1135. https://doi. org/10.1017/S0016756813000162.

Costa, L.I. \& Davey, R.J. 1992: Dinoflagellate cysts of the Cretaceous System. In Powell, A.J. (ed.): A Stratigraphic Index of Dinoflagellate Cysts, British Micropalaeontological Society Publication Series, Tracy \& Chapman, pp. 99-153. https://doi.org/10.1007/978-94-011-2386-0_3.

Duxbury, S. 1980: Barremian phytoplankton from Speeton, East Yorkshire. Palaeontographica Abteilung B 173, 107-146.
Duxbury, S. 2001: A palynological zonation scheme for the Lower Cretaceous - United Kingdom sector, central North Sea. Neues Jahrbuch für Geologie und Paläontologie, Abhandlungen 219, 97-137. https://doi.org/10.1127/njgpa/219/2001/95.

Dypvik H. 1985: Jurassic and Cretaceous black shales of the Janusfjellet Formation, Svalbard, Norway. Sedimentary Geology 41, 235-248. https://doi.org/10.1016/0037-0738(84)90064-2.

Dypvik H., Nagy J., Eikeland, T.A., Backer-Owe, K., Andresen, A., Haremo, P., Bjærke, T., Johansen, H. \& Elverhøi, A. 1991a: The Janusfjellet Subgroup (Bathonian to Hauterivian) on central Spitsbergen: a revised lithostratigraphy. Polar Research 9, 21-43. https://doi.org/10.1111/j.1751-8369.1991.tb00400.x.

Dypvik H., Nagy J., Eikeland, T.A., Backer-Owe K. \& Johansen H. 1991b: Depositional conditions of the Bathonian to Hauterivian Janusfjellet Subgroup, Spitsbergen. Sedimentary Geology 72, 55-78. https://doi.org/10.1016/0037-0738(91)90123-U.

Dörr, N., Fisker, F., Clift, P.D., Carter, A., Gee, D.G., Tebenkov, A.M. \& Spiegel, C. 2012: Late Mesozoic-Cenozoic exhumation history of northern Svalbard and its regional significance: Constraints from apatite fission track analysis. Tectonophysics 514-517, 81-92. https://doi.org/10.1016/j.tecto.2011.10.007.

Edwards, M.B. 1976: Depositional environments in Lower Cretaceous regressive sediments, Kikutodden, Sørkapp Land, Svalbard. Norsk Polarinstitutt Årbok 1974, 35-50.

Edwards M.B. 1979: Sandstone in Lower Cretaceous Helvetiafjellet Formation, Svalbard: Bearing on Reservoir Potential of the Barents Shelf. American Association of Petroleum Geologists Bulletin 63, 2193-2203.

Gjelberg, J. \& Steel, R.J. 1995: Helvetiafjellet Formation (BarremianAptian), Spitsbergen: characteristics of a transgressive succession. In Steel, R.J., Felt, V.L., Johannesen, E.P. \& Mathieu, C. (eds.): Sequence Stratigraphy on the Northwest European Margin, Norwegian Petroleum Society Special Publications 5, pp. 571-593. https://doi.org/10.1016/S0928-8937(06)80087-1.

Grøsfjeld K. 1992: Palynological age constraints on the base of the Helvetiafjellet Formation (Barremian) on Spitsbergen. Polar Research 11, 11-19. https://doi.org/10.1111/j.1751-8369.1992.tb00408.x.

Grundvåg, S.-A. \& Olaussen, S. 2017: Sedimentology of the Lower Cretaceous at Kikutodden and Keilhaufjellet, southern Spitsbergen: implications for an onshore offshore link. Polar Research 36. https://doi.org/10.1080/17518369.2017.1302124.

Grundvåg, S.-A., Marin, D., Kairanov, B., Śliwińska, K.K., NøhrHansen, H., Jelby, M.E., Escalona, A. \& Olaussen, S. 2017: The Lower Cretaceous succession of the northwestern Barents Shelf: Onshore and offshore correlations. Marine and Petroleum Geology 86, 834-857. https://doi.org/10.1016/j.marpetgeo.2017.06.036.

Hovikoski, J., Pedersen, G.K., Alsen, P., Lauridsen, B.W., Svennevig, K., Nøhr-Hansen, H., Sheldon, E., Dybkjær, K., Bojesen-Koefoed, J., Piasecki, S., Bjerager, M. \& Ineson, J. 2018: The Jurassic-Cretaceous lithostratigraphy of Kilen, Kronprins Christian Land, eastern North Greenland. Bulletin of the Geological Society of Denmark 66, 61-112.

Hurum, J., Druckenmiller, P.S., Hammer, Ø., Nakrem, H.A. \& Olaussen, S. 2016a: The theropod that wasn't: an ornithopod tracksite from the Helvetiafjellet Formation (Lower Cretaceous) of Boltodden, Svalbard. In Kear, B.P., Lindgren, J., Hurum, J.H., Milan, J. \& Vajda, V. (eds.): Mesozoic Biotas of Scandinavia and its Arctic Territories. Geological Society, London, Special Publications 434.

Hurum, J.H., Dyke, G., Roberts, A.J., Grundvåg, S.A., Nakrem, H.A., Midtkandal, I., Śliwińska, K.K. \& Olaussen, S. 2016b: An avialan femur from Albian strata on Spitsbergen, Arctic Norway. Palaeontologia Polonica 67, 137-147. 
Hvoslef, S., Dypvik, H. \& Solli, H. 1986: A combined sedimentological and organic geochemical study of the Jurassic/Cretaceous Janusfjellet Formation (Svalbard), Norway. Organic Geochemistry $10,101-111$.

https://doi.org/10.1016/0146-6380(86)90013-6.

Isaksen, G.H. \& Ledje, H.I. 2001: Source rock quality and hydrocarbon migration pathways within the greater Utsira High area, Viking Graben, Norwegian North Sea. American Association of Petroleum Geologists Bulletin 85, 861-883.

Kairanov, B., Escalona, A., Mordasova, A., Śliwińska, K.K. \& Suslova, A. 2018: Early Cretaceous tectonostratigraphic evolution of the north central Barents Sea. Journal of Geodynamics 119, 183-198. https://doi.org/10.1016/j.jog.2018.02.009.

Kneller, B. \& Branney, M.J. 1995: Sustained high-density turbidity currents and the deposition of thick massive sands. Sedimentology 42, 607-616. https://doi.org/10.1111/j.1365-3091.1995.tb00395.x.

Koevoets, M., Abay, T.B., Hammer, Ø. \& Olaussen, S. 2016: Highresolution organic carbon-isotope stratigraphy of the Middle Jurassic-Lower Cretaceous Agardhfjellet Formation of central Spitsbergen, Svalbard. Palaeogeography, Palaeoclimatology, Palaeoecology 449, 266-274. https://doi.org/10.1016/j.palaeo.2016.02.029.

Koevoets, M.J., Hammer, Ø., Olaussen, S., Senger, K. \& Smelror, M. 2019: Integrating subsurface and outcrop data of the Middle Jurassic to Lower Cretaceous Agardhfjellet Formation in central Spitsbergen. Norwegian Journal of Geology 99, 213-246. https://dx.doi.org/10.17850/njg98-4-01.

Lowe, D.R. 1982: Sediment gravity flows: II. Depositional models with special reference to the deposits of high density turbidity currents. Journal of Sedimentary Petrology 52, 279-297.

Løfaldi, M. \& Thusu, B. 1976: Microfossils from the Janusfjellet Subgroup (Jurassic-Lower Cretaceous) at Agardhfjellet and Keilhaufjellet, Spitsbergen. A preliminary report. Norsk Polarinstitutt Årbok 1975, 69-77.

MacEachern, J A., Bann, K.L., Pemberton, S.G. \& Gingras, M.K. 2007: The ichnofacies paradigm: high-resolution paleo environmental interpretation of the rock record. In MacEachern J.A., Bann, K.L., Gingras, M.K. \& Pemberton, S.G. (eds.): Applied ichnology, Society of Economic Paleontologists and Mineralogists Short Course Notes 52, pp. 27-64.

Mackenzie, A.S., Leuthaeuser, D., Schaefer, R.G. \& Bjorøy, M. 1983: Expulsion of hydrocarbons from shale source rocks. Nature 301, 506-509. https://doi.org/10.1038/301506a0.

Magnabosco, C., Braathen, A. \& Pgata, K. 2014: Permeability model of tight reservoir sandstones combining core-plug and Miniperm analysis of drillcore; Longyearbyen $\mathrm{CO}_{2} \mathrm{Lab}$, Svalbard. Norwegian Journal of Geology 94, 189-200.

Maher, H.D. 2001: Manifestations of the Cretaceous High Arctic Large Igneous Province in Svalbard. Journal of Geology 109, 91-104. https://doi.org/10.1086/317960.

Maher, H.D., Hays, T., Shuster, R. \& Mutrux, J. 2004: Petrography of the Lower Cretaceous sandstones of Spitsbergen. Polar Research 23, 147-165. https://doi.org/10.1111/j.1751-8369.2004.tb00005.x.

Marin, D., Escalona, A., Śliwińska, K.K., Nøhr-Hansen, H. \& Mordasova, A. 2016: Sequence stratigraphy and lateral variability of Lower Cretaceous clinoforms in the SW Barents Sea. American Association of Petroleum Geologists Bulletin 101, 1487-1517.

Marshall, C., Uguna, J., Large, D.J., Meredith, W., Jochmann, M., Friis, B., Vane, C., Spiro, B.F., Snape, C.E. \& Orheim, A. 2015: Geochemistry and petrology of Palaeocene coals from Spitzbergen - part 2: maturity variations and implications for local and regional burial models. International Journal of Coal Geology 143, 1-10. https://doi.org/10.1016/j.coal.2015.03.013.

Midtkandal, I. \& Nystuen, J.P. 2009: Depositional architecture of a lowgradient ramp shelf in an epicontinental sea: the lower Cretaceous of Svalbard. Basin Research 21, 655-675.

https://doi.org/10.1111/j.1365-2117.2009.00399.x.
Midtkandal, I., Nystuen, J.P. \& Nagy, J. 2007: Paralic sedimentation on an epicontinental ramp shelf during a full cycle of relative sea-level fluctuation; the Helvetiafjellet Formation in Nordenskiold Land, Spitsbergen. Norwegian Journal of Geology 87, 343-359.

Midtkandal, I., Nystuen, J.P., Nagy, J. \& Mørk, A. 2008. Lower Cretaceous lithostratigraphy across a regional subaerial unconformity in Spitsbergen: the Rurikfjellet and Helvetiafjellet formations. Norwegian Journal of Geology 88, 287-304.

Midtkandal, I., Svensen, H., Planke, S., Corfu, F., Polteau, S., Torsvik, T., Faleide, J.I., Grundvåg, S.-A., Selnes, H. \& Olaussen, S. 2016: The Aptian oceanic anoxic event (OAEla) in Svalbard and the age of the Barremian-Aptian boundary. Palaeogeography, Palaeoclimatology, Palaeoecology 463, 126-135. https://doi.org/10.1016/j.palaeo.2016.09.023.

Mork-Jansson, W.A., Mørk, A., Olaussen, S. \& Helland-Hansen, W. 2010: Lower Cretaceous gravity and sandy shelf deposits in Adventdalen, Spitsbergen - a response of local tectonics? In Brekke et al (eds.): Arctic Days 2010 NGF, Abstracts and Proceedings of the Geological Society of Norway, pp. 36.

Mulder, T. \& Syvitski, J.P.M. 1995: Turbidity currents generated at river mouths during exceptional discharges to the world oceans. The Journal of Geology 103, 285-299. https://doi.org/10.1086/629747.

Mutrux, J., Maher, H., Shuster, R. \& Hays, T. 2008: Iron ooid beds of the Carolinefjellet Formation, Spitsbergen, Norway. Polar Research 27, 28-43. https://doi.org/10.1111/j.1751-8369.2007.00039.x.

Nagy, J. 1970: Ammonite faunas and stratigraphy of Lower Cretaceous (Albian) rocks in southern Spitsbergen. Norsk Polarinstitutt Skrifter $152,1-58$.

Neill, C.F. \& Allison, M.A. 2005: Subaqueous deltaic formation on the Atchafalaya Shelf, Louisiana. Marine Geology 214, 411-430. https:// doi.org/10.1016/j.margeo.2004.11.002.

Nemec, W. 1992: Depositional controls on plant growth and peat accumulation in a braidplain delta environment: Helvetiafjellet Formation (Barremian-Aptian), Svalbard. In McCabe, P.J. \& Parish, J.T. (eds.): Controls on the Distribution and Quality of Cretaceous Coals, Geological Society of America Special Paper 267, pp. 209-226. https://doi.org/10.1130/SPE267-p209.

Nemec, W., Steel, R.J., Gjelberg, J., Collinson, J.D., Prestholm, E. \& Øxnevad, I.E. 1988: Anatomy of Collapsed and Re-established Delta front in Lower Cretaceous of Eastern Spitsbergen: Gravitational Sliding and Sedimentation Processes. American Association of Petroleum Geologists Bulletin 72, 454-476.

Nøttvedt, A. \& Kreisa, R. 1987: Model for the combined-flow origin of hummocky cross-stratification. Geology 15, 357-361. https://doi. org/10.1130/0091-7613(1987)15<357:MFTCOO>2.0.CO;2.

Nøttvedt, A., Livbjerg, F., Midbøe, P.F. \& Rasmussen, E. 1993: Hydrocarbon potential of the Central Spitsbergen Basin. In Vorren, T.O., Bergsager, E., Dahl-Stamnes, Ø.A., Holter, E., Johansen, B., Lie, E. \& Lund, T. (eds.): Arctic Geology and Petroleum Potential, Norwegian Petroleum Society Special Publication 2, pp. 333-361. https://doi.org/10.1016/B978-0-444-88943-0.50026-5.

Nøhr-Hansen, H. 1993: Dinoflagellate cyst stratigraphy of the Barremian to Albian, Lower Cretaceous, north-east Greenland. Grønlands Geologiske Undersøgelse Bulletin 166, 1-171.

Nøhr-Hansen, H. 2012: Palynostratigraphy of the Cretaceous - lower Palaeogene sedimentary succession in the Kangerlussuaq Basin, southern East Greenland. Review of Palaeobotany and Palynology 178, 59-90. https://doi.org/10.1016/j.revpalbo.2012.03.009.

Onderdonk, N. \& Midtkandal, I. 2010: Mechanisms of collapse of the cretaceous helvetiafjellet formation at Kvalvågen, eastern Spitsbergen. Marine and Petroleum Geology 27, 2118-2140. https:// doi.org/10.1016/j.marpetgeo.2010.09.004.

Parker J.R. 1967: The Jurassic and Cretaceous Sequence in Spitsbergen. Geological Magazine 104, 487-505.

https://doi.org/10.1017/S0016756800049220. 
Parsons, J.D., Bush, J.W. \& Syvitski, J.P.M. 2001: Hyperpycnal plume formation from riverine outflows with small sediment concentrations. Sedimentology 48, 465-478.

https://doi.org/10.1046/j.1365-3091.2001.00384.x.

Peters, K.E. \& Cassa, M.R. 1994: Applied source rock geochemistry. In Magoon, L.B. \& Dow, W.G. (eds): The Petroleum System - From Source to Trap, American Association of Petroleum Geologists Memoirs 60, pp. 93-117.

Pickton, C.A.G. 1981: Palaeogene and Cretaceous dropstones in Spitsbergen. In Hambrey, M.J. \& Harland, W.B. (eds.): Earths prePleistocene glacial record, Cambridge University Press, pp. 567-569.

Polteau, S., Hendriks, B.W.H., Planke, S., Ganerød, M., Corfu, F., Faleide, J.I., Midtkandal, I., Svensen, H.S. \& Myklebust, R. 2016: The Early Cretaceous Barents Sea sill complex: distribution, 40Ar/39Ar geochronology, and implications for carbon gas formation. Palaeogeography, Palaeoclimatology, Palaeoecology 441, 83-95. https://doi.org/10.1016/j.palaeo.2015.07.007.

Price, G.D. \& Nunn, E.V. 2010: Valanginian isotope variation in glendonites and belemnites from Arctic Svalbard: Transient glacial temperatures during the Cretaceous greenhouse. Geology 38, 251254. https://doi.org/10.1130/G30593.1.

Price, G.D. \& Passey, B.H. 2013: Dynamic polar climates in a greenhouse world: evidence from clumped isotope thermometry of Early Cretaceous belemnites. Geology 41, 923-926.

https://doi.org/10.1130/G34484.1.

Røhr, T.S., Andersen, T. \& Dypvik, H. 2007: Provenance of Lower Cretaceous sediments from Svalbard and NE Greenland: A detrital zircon study. Goldschmidt Conference Abstracts 2007, pp. A848.

Røhr, T.S., Andersen, T. \& Dypvik, H. 2008: Provenance of Lower Cretaceous sediments in the Wandel Sea Basin, North Greenland. Journal of the Geological Society 165, 755-767. https://doi. org/10.1144/0016-76492007-102.

Røhr, T.S., Andersen, T., Dypvik, H. \& Embry, A.F. 2010: Detrital zircon characteristics of the Lower Cretaceous Isachsen Formation, Sverdrup Basin: source constraints from age and Hf isotope data. Canadien Journal of Earth Sciences 47, 255-271. https://doi.org/10.1139/E10-006.

Sarjeant, W.A.S. 1966: Dinoflagellate cysts with Gonyaulax-type tabulation. In Davey, R.J., Downie, C., Sarjeant, W.A.S. \& Williams, G.L. (eds.): Studies on Mesozoic and Cainozoic dinoflagellate cysts, British Museum (Natural History) Geology Bulletin, Supplement 3, pp. 107-156.

Senger, K., Tveranger J., Ogata, K., Braathen A. \& Planke, S. 2014: Late Mesozoic magmatism in Svalbard: a review. Earth-Science Reviews $139,123-144$. https://doi.org/10.1016/j.earscirev.2014.09.002.

Shanmugam, G. 1996: High-density turbidity currents: are they sandy debris flows? Journal of Sedimentary Research 66, 2-10. https://doi.org/10.1306/D426828E-2B26-11D7-8648000102C1865D.

Smelror, M. \& Larssen, G.B. 2016: Are there Upper Cretaceous sedimentary rocks preserved on Sørkapp Land, Svalbard? Norwegian Journal of Geology 96, 147-158. http://dx.doi.org/10.17850/njg96-2-05.

Smith, D.G. \& Pickton, C.A.G. 1976: The Helvetiafjellet Formation (Cretaceous) of North-East Nordenskiold Land, Spitsbergen. Norsk Polarinstitutt Skrifter 164, 47-55.

Steel, R.J. 1977: Observations on some Cretaceous and Tertiary sandstone bodies in Nordenskiöld Land, Svalbard. Norsk Polarinstitutt Årbok 1976, 43-68.

Steel, R.J. \& Worsley, D. 1984: Svalbard's post-Caledonian strata - an atlas of sedimentational patterns and palaeogeographic evolution. In Spencer, A.M. (ed.): Petroleum Geology of the North European Margin, Norwegian Petroleum Society, pp. 109-135. https://doi. org/10.1007/978-94-009-5626-1_9.
Steel, R.J., Gjelberg, J. \& Haarr, G. 1978: Helvetiafjellet Formation (Barremian) at Festningen, Spitsbergen - a field guide. Norsk Polarinstitutt Årbok 1978, 111-128.

Steel, R.J., Gjelberg, J., Helland-Hansen, W., Kleinspehn, K., Nøttvedt, A. \& Rye-Larsen, M. 1985: The Tertiary strike-slip basins and orogenic belt of Spitsbergen. Society of Economic Paleontologists and Mineralogists Special Publication 37, 339-359. https://doi.org/10.2110/pec.85.37.0339.

Steel, R.J., Crabaugh, J., Schellpepper, M., Mellere, D., Plink-Björklund, P., Deibert, J. \& Løseth, T. 2000: Deltas vs. rivers on the shelf edge: their relative contributions to the growth of shelf-margins and basin-floor fans (Barremian and Eocene, Spitsbergen). In P. Weimer et al. (eds.), Deep-water reservoirs of the world. Proceedings of the GCSSEPM Foundation $20^{\text {th }}$ Annual Research Conference, pp. 981-1009. https://doi.org/10.5724/gcs.00.15.0981.

Taylor, A.M. \& Goldring, R. 1993: Description and analysis of bioturbation and ichnofabric. Journal of the Geological Society London 150, 141-148. https://doi.org/10.1144/gsjgs.150.1.0141.

Tennvassås, I. 2018: Characterisation of palaeosols in the Lower Cretaceous Helvetiafjellet Formation, Svalbard: palaeo-climatic implications. Unpublished MSc thesis, UiT The Arctic University of Norway, $167 \mathrm{pp}$.

Torsvik, T.H., Carlos, D., Mosar, J., Cocks, L.R.M. \& Malme, T. 2002: Global reconstructions and North Atlantic palaeogeography $400 \mathrm{Ma}$ to Recent. In Eide, E.A. (ed.): BATLAS - Mid Norway plate reconstructions atlas with global and Atlantic perspectives, Geological Survey of Norway, pp. 18-39.

Tullius, D.N., Leier, A.L., Galloway, J.M., Embry, A.F. \& Pedersen, P.K. 2014: Sedimentology and stratigraphy of the Lower Cretaceous Isachsen Formation: Ellef Ringnes Island, Sverdrup Basin, Canadian Arctic Archipelago. Marine and Petroleum Geology 57, 135-151. https://doi.org/10.1016/j.marpetgeo.2014.05.018.

Vickers, M.L., Price, G.D., Jerrett, R.M., \& Watkinson, M. 2016: Stratigraphic and geochemical expression of Barremian-Aptian global climate change in Arctic Svalbard. Geosphere 12, 1-12. https://doi.org/10.1130/GES01344.1.

Vickers, M., Watkinson, M., Price, G.D. \& Jerrett, R. 2018: An improved model for the ikaite-glendonite transformation: evidence from the Lower Cretaceous of Spitsbergen, Svalbard. Norwegian Journal of Geology 98, 1-15.

https://dx.doi.org/10.17850/njg98-1-01.

Worsely, D. 1986: The geological history of Svalbard - evolution of an arctic archipelago. Den Norske Stats Oljeselskap AS, Stavanger, Norway, $121 \mathrm{pp}$.

Århus, N. 1991: Dinoflagellate cyst stratigraphy of some Aptian and Albian sections from North Greenland, southeastern Spitsbergen and the Barents Sea. Cretaceous Research 12, 209-225. https://doi. org/10.1016/0195-6671(91)90035-B.

Århus, N. 1992: Some dinoflagellate cysts from the Lower Cretaceous of Spitsbergen. Grana 31, 305-314. https://doi.org/10.1080/00173139209429453.

Århus, N., Kelly, S.R.A., Collins, J.S.H. \& Sandy, M.R. 1990: Systematic palaeontology and biostratigraphy of two Early Cretaceous condensed sections from the Barents Sea. Polar Research 8, 165194. https://doi.org/10.1111/j.1751-8369.1990.tb00383.x. 